\title{
Synthesis of Eosinophil Infiltration Inhibitors with Antihistaminic Activity
}

\author{
Michiyo Gyoten, ${ }^{*}$ Hideaki Nagaya, Shigeru Fukuda, Yasuko Ashida, and Yasuhiko Kawano \\ Pharmaceutical Research Division, Takeda Chemical Industries, Ltd.; 2-17-85 Jusohonmachi, Yodogawa-ku, Osaka \\ 532-8686, Japan. Received August 5, 2002; accepted December 2, 2002
}

\begin{abstract}
A series of $[1,2,4]$ triazolo[1,5-b]pyridazines (5) and imidazo[1,2-b]pyridazines (6) having cyclic amines was synthesized and evaluated for antihistaminic activity and inhibitory effect on eosinophil infiltration. When a piperidine or a piperazine containing a benzhydryl group and a suitable spacer was incorporated at the 6-position, the fused pyridazines were found to exhibit both antihistaminic activity and an inhibitory effect on eosinophil chemotaxis. Above all, 6a showed potent antihistaminic activity, but little blockade of central $\mathrm{H}_{1}$ receptors in contrast with its complete blockade of peripheral $\mathrm{H}_{1}$ receptors as determined by an ex vivo binding assay. Furthermore, $6 \mathrm{a}$ inhibited eosinophil infiltration of the skin caused by a topical antigen challenge in sensitized guinea pigs, while an antihistamine terfenadine was not effective. After the pharmacokinetic study, 6a was found to be rapidly hydrolyzed to 6o, which was also orally active. Compound 6o, 2-[6-[[3-[4-(diphenylmethoxy)piperidino]propyl]amino]imidazo[1,2-b]pyridazin-2-yl]-2-methylpropionic acid dihydrate (TAK-427), having both antihistaminic and antiinflammatory activity, is currently undergoing clinical trials as a therapeutic agent for atopic dermatitis and allergic rhinitis.
\end{abstract}

Key words imidazo[1,2-b]pyridazine; atopic dermatitis; eosinophil infiltration; brain penetrability; antihistaminic activity; structure-activity relationship

Atopic dermatitis is thought to be caused by allergic inflammation in response to various antigens in predisposed individuals, and is accompanied by an itching sensation. The scratching behavior often observed in patients with atopic dermatitis exacerbates the dermal inflammation. ${ }^{1)}$

Histamine, which is released from mast cells and basophils on antigenic stimulation, plays a central role in itching. ${ }^{2)}$ Eosinophils have been implicated in the pathogenesis of allergic disease. An increase in the number of peripheral eosinophils and the concentration of eosinophil cationic protein in serum is related to the severity of atopic disease, ${ }^{3)}$ and deposits of eosinophil-derived granules are observed in chronic atopic dermatitis. ${ }^{4)}$ Thus, eosinophil infiltration is an important factor in allergic inflammation.

Topical glucocorticoids are generally used for the treatment of atopic dermatitis, and antihistamines are also administered to suppress the itching sensation. However, the use of glucocorticoids bring about side effects such as local skin atrophy, ${ }^{1)}$ and classical antihistamines have sedative side effects due to their interaction with central $\mathrm{H}_{1}$ receptors. ${ }^{5}$ ) Therefore, we planned to develop a new type of agent, having an inhibitory effect on eosinophil infiltration and antihistaminic activity without the sedative side effects.

We have observed that some fused pyridazine derivatives had an inhibitory effect on the leukotriene (LT) $\mathrm{B}_{4}$-stimulated chemotaxis of guinea pig peritoneal eosinophils. ${ }^{6,7)}$ Then, we selected the fused pyridazine ring as a scaffold. Additionally, the incorporation of cyclic amines such as a piperidine or piperazine containing a benzhydryl group, both of which are in common in some antihistamines, may bring about antihistaminic activity. We describe here the synthesis and pharmacological evaluation of fused pyridazines having a cyclic amino group.

\section{Chemistry}

The synthesis of the desired $[1,2,4]$ triazolo[1,5- $b]$ pyridazines (5; listed in Table 1) and imidazo[1,2-b]pyridazines
(6; listed in Table 3) was carried out via the route outlined in Chart 1 . When the $\mathrm{Z}$ group, which is a linker between the fused ring and a cyclic amine containing a benzhydryl group, is $\mathrm{NH}$ or $\mathrm{NCH}_{3}$, the compounds $\mathbf{5}$ and $\mathbf{6}$ were synthesized by a one-step condensation of azoles $(\mathbf{1}, \mathbf{2})$ and amines $(3)$, or by a three-step sequence, i.e. amination of the azoles $(\mathbf{1}, \mathbf{2})$ with aminoalcohols (7), mesylation of the resulting alcohols $(\mathbf{1 0 a}, \mathbf{b})$, and amination with cyclic amines (11). The compounds having an oxygen atom as a linker $(\mathbf{5}, \mathbf{6} ; \mathrm{Z}=\mathrm{O})$ were synthesized by condensation of the azoles $(\mathbf{1}, \mathbf{2})$ and alcohols (4) using a base. However, in the case of the ester derivative (6b), the trans-esterification mainly occurred in the reaction of the ethyl ester (2d) and the corresponding alcohol (4; $n=3$ ) in the presence of a base. Therefore, the azole substituted with a bulky ester group (2h) was used instead of $\mathbf{2 c}$ or $\mathbf{2 d}$ for the preparation of $\mathbf{6 b}$ (shown in Experimental section). The compounds having a sulfur atom as a linker (5, 6; $\mathrm{Z}=\mathrm{S}$ ) were synthesized by the following method. The azoles $(\mathbf{1}, \mathbf{2})$ were treated with ethyl 3-mercaptopropionate in the presence of sodium methoxide to afford 6-azolylthiolates, which were alkylated with 1-bromo-3-halogenated propanes (8), and the resulting halides $(\mathbf{1 0 c}, \mathbf{d})$ were condensed with the cyclic amines (11). Imidazo[1,2-b]pyridazine with a carbon side chain introduced directly at the 6-position (6; $\mathrm{Z}=\mathrm{CH}_{2}$ ) was obtained by cross coupling of the azole (2) and an organo zinc reagent ${ }^{8)}$ in the presence of dichlorobis(triphenylphosphine)palladium(II), followed by alkylation of the cyclic amine (11) with the resulting halide (10e).

A $[1,2,4]$ triazolo[1,5-b]pyridazine ring having a tert-butyl group at the 2-position (1d) was constructed by the method shown in Chart 2. Condensation of 3-amino-6-chloropyridazine (12) $)^{9)}$ and a Vilsmeier-type reagent was followed by the treatment of the resulting amidine with hydroxylamine, which provided an amidoxime (14). Cyclization of 14 using phosphorus oxychloride afforded a $[1,2,4]$ triazolo[1,5-b]pyridazine skeleton (1d). The compound having a methoxycarbonyl group (1e) was synthesized by oxidation of $1 \mathbf{c},{ }^{10)}$ fol- 


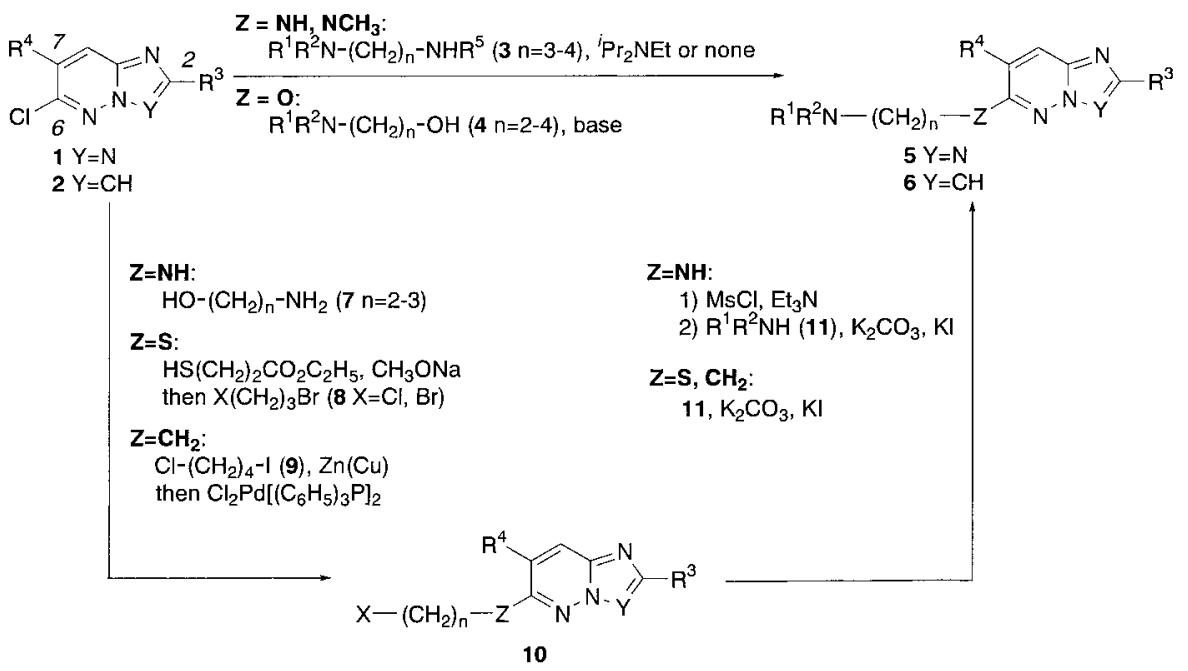

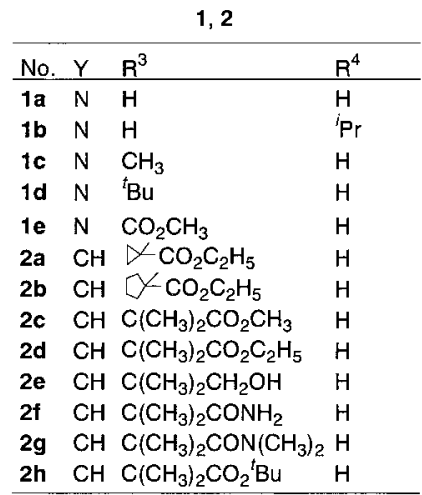

\begin{tabular}{lllllll}
\multicolumn{7}{c}{10} \\
\hline No. & $\mathrm{X}$ & $\mathrm{n}$ & $\mathrm{Z}$ & $\mathrm{Y}$ & $\mathrm{R}^{3}$ & $\mathrm{R}^{4}$ \\
\hline 10a & $\mathrm{OH}$ & 2 & $\mathrm{NH}$ & $\mathrm{N}$ & $\mathrm{H}$ & $\mathrm{H}$ \\
10b & $\mathrm{OH}$ & 3 & $\mathrm{NH}$ & $\mathrm{N}$ & $\mathrm{H}$ & $\mathrm{H}$ \\
10c & $\mathrm{Br}$ & 3 & $\mathrm{~S}$ & $\mathrm{~N}$ & $\mathrm{H}$ & $\mathrm{H}$ \\
10d & $\mathrm{Cl}$ & 3 & $\mathrm{~S}$ & $\mathrm{CH}$ & $\mathrm{C}\left(\mathrm{CH}_{3}\right)_{2} \mathrm{CO}_{2} \mathrm{CH}_{3}$ & $\mathrm{H}$ \\
10e & $\mathrm{Cl}$ & 3 & $\mathrm{CH}_{2}$ & $\mathrm{CH}$ & $\mathrm{C}\left(\mathrm{CH}_{3}\right)_{2} \mathrm{CO}_{2} \mathrm{C}_{2} \mathrm{H}_{5}$ & $\mathrm{H}$ \\
\hline
\end{tabular}

11a $\mathrm{Ph}_{2} \mathrm{CHO}-\mathrm{NH}^{\mathrm{NH}}: \mathrm{R}^{1} \mathrm{R}^{2} \mathrm{NH}$

Chart 1

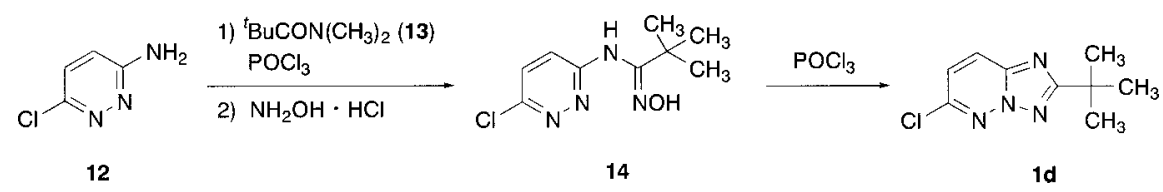

Chart 2<smiles>Cc1nc2ccc(Cl)nn2n1</smiles>

$1 c$

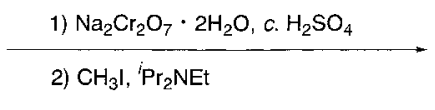

Chart 3<smiles>CC(=O)c1nc2ccc(Cl)nn2n1</smiles>

$1 e$ lowed by esterification (Chart 3). Other [1,2,4]triazolo[1,5$b]$ pyridazines were prepared according to reported procedures. $^{10-12)}$

Imidazo[1,2-b]pyridazines $(\mathbf{2 a}-\mathbf{h})$ were synthesized as shown in Chart 4. Compound $\mathbf{1 2}$ was condensed with methyl 4-chloroacetoacetate (15), and alkylation of the resulting $\mathbf{2 i}$ gave dialkylated or cycloalkylated compounds $(\mathbf{2 a}-\mathbf{c})$. However, this method was found not to be adequate to afford the desired compounds in a large-scale preparation because of a deep coloration and a low yield. Therefore, an alternative route was investigated. The dimethyl group of the isobutylic acid moiety in $\mathbf{2 d}$ was introduced before construction of the imidazo[1,2-b]pyridazine ring; the dimethylated compound
(16) ${ }^{13)}$ was used for condensation with 12. The ethyl ester (2d) obtained was hydrolyzed in an alkaline solution, and esterification of the resulting carboxylic acid (2j) using $N, N$-dimethylformamide di-tert-butylacetal gave the tert-butyl ester (2h). In addition, compound $\mathbf{2 j}$ was treated with $N, N^{\prime}$-carbonyldiimidazole (CDI) and the resulting imidazolide was reduced using tetrabutylammonium borohydride to an alcohol (2e). Treatment of this imidazolide with amines also afforded the corresponding amides $(\mathbf{2} \mathbf{f}, \mathbf{g})$.

The amines $\mathbf{3 a}-\mathbf{d}$ were synthesized by condensation of the cyclic amines (11) ${ }^{14-16)}$ and $N$-(3-bromopropyl)phthalimide (17), followed by hydrazinolysis of the phthalimide group (Chart 5). The $N$-methylated compound (3e) was obtained by 

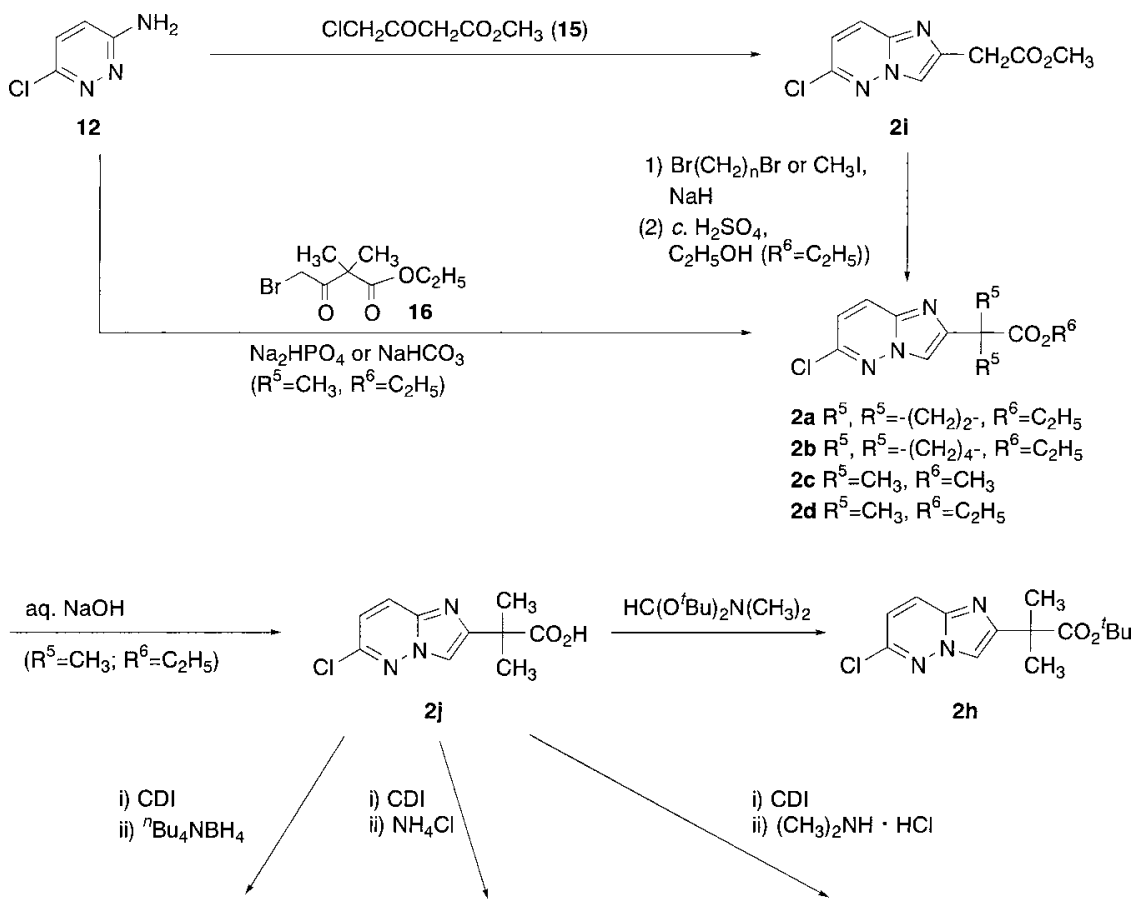

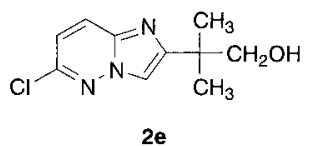

$2 \mathrm{e}$

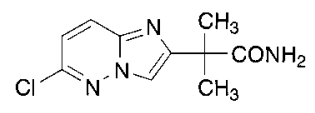

$2 f$

Chart 4 2h<smiles></smiles>

$2 \mathrm{~g}$

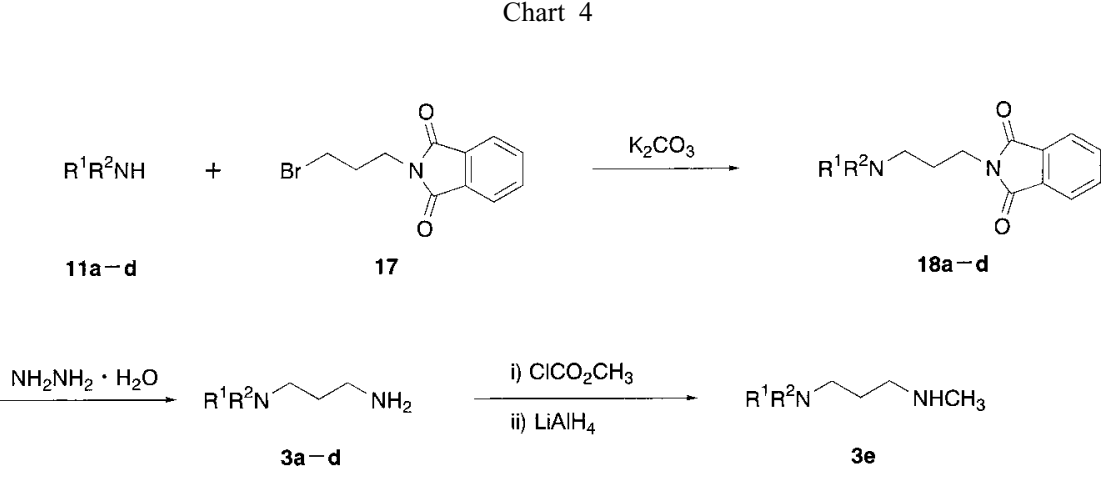

Chart 5

methoxycarbonylation of 3a with methyl chloroformate, followed by lithium aluminum hydride reduction.

Alkylation of the cyclic amines (11) with (bromoalkyl)alcohols (chart not shown) gave the corresponding alcohols (4; shown in Chart 1).

\section{Results and Discussion}

Screening Assays The compounds synthesized were initially tested for antihistaminic activity (in vitro and in vivo) and an inhibitory effect on eosinophil chemotaxis (in vitro). In vitro antihistaminic activity was assessed using isolated guinea pig tracheal strips. In vivo antihistaminic activity was evaluated from the inhibitory effect on the histamine-induced increase in microvascular permeability in the guinea pig skin. The inhibitory effect on the chemotaxis of guinea pig peritoneal eosinophils in response to $\mathrm{LTB}_{4}$ was assessed using a modified Boyden's chamber method. TAK-225, 2-ethyl-2[[(7-methyl[1,2,4]triazolo[1,5-b]pyridazin-6-yl)oxy]methyl]butane-1-sulfonamide, ${ }^{6,7)}$ was employed as a reference com- pound.

Some compounds were evaluated for their brain penetrability, using an ex vivo $\left[{ }^{3} \mathrm{H}\right]$ pyrilamine binding assay. Compounds were administered orally to guinea pigs $1 \mathrm{~h}$ before they were sacrificed, and their lungs and cerebral cortexes were removed and homogenized, then the specific binding of $\left[{ }^{3} \mathrm{H}\right]$ pyrilamine to the membranes was determined. The decrease in the specific binding of $\left[{ }^{3} \mathrm{H}\right]$ pyrilamine reflects the in vivo occupancy of test compounds to $\mathrm{H}_{1}$ receptors.

The effects of $[1,2,4]$ triazolo[ $1,5-b]$ pyridazine derivatives (5) on the screening assays are summarized in Table 1. It was found that most of the compounds listed in Table 1 have potent in vitro and in vivo antihistaminic activity, however, the introduction of an isopropyl group at the 7-position of the $[1,2,4]$ triazolo[1,5-b]pyridazine ring (5d) attenuated in vivo activity.

In regard to eosinophil chemotaxis, the inhibitory activity of 5a having a piperidinyl group was higher than that of $\mathbf{5 b}$ having a piperazinyl group. Comparison of the atoms $(Z)$ at 
Table 1. Antihistaminic and Eosinophil Chemotaxis Inhibitory Effects of $[1,2,4]$ Triazolo[1,5- $b]$ pyridazine Derivatives

\begin{tabular}{|c|c|c|c|c|c|c|c|c|}
\hline \multirow[b]{2}{*}{ No. } & \multirow[b]{2}{*}{$\mathrm{R}^{1} \mathrm{R}^{2} \mathrm{~N}^{b)}$} & \multirow[b]{2}{*}{$n$} & \multirow[b]{2}{*}{$\mathrm{Z}$} & \multirow[b]{2}{*}{$\mathrm{R}^{3}$} & \multirow[b]{2}{*}{$\mathrm{R}^{4}$} & \multicolumn{2}{|c|}{ Antihistaminic activities } & \multirow{2}{*}{$\begin{array}{c}\text { Eosinophil } \\
\text { chemotaxis }^{e} \\
\% \text { inh. } \\
\left.\text { (at } 10^{-5} \mathrm{M}\right)\end{array}$} \\
\hline & & & & & & $\begin{array}{c}\mathrm{H}_{1} \text { in vitro }{ }^{c)} \% \text { inh. } \\
\left(\text { at } 10^{-5} \mathrm{M}\right)\end{array}$ & $\begin{array}{l}\mathrm{H}_{1} \text { in vivo }{ }^{d)} \% \text { inh. } \\
\quad(3 \mathrm{mg} / \mathrm{kg}, \text { p.o. })\end{array}$ & \\
\hline $5 \mathbf{a}$ & A & 3 & $\mathrm{NH}$ & $\mathrm{H}$ & $\mathrm{H}$ & 98 & $91 * *$ & $64(37)$ \\
\hline $5 b$ & B & 3 & $\mathrm{NH}$ & $\mathrm{H}$ & $\mathrm{H}$ & 100 & $89 * *$ & $11(37)$ \\
\hline $5 c^{a)}$ & A & 3 & $\mathrm{O}$ & $\mathrm{H}$ & $\mathrm{H}$ & 100 & $86^{* *}$ & $54(37)$ \\
\hline $5 \mathbf{d}^{a)}$ & A & 3 & $\mathrm{O}$ & $\mathrm{H}$ & ${ }^{i} \mathrm{Pr}$ & 90 & $53 * *$ & $32(37)$ \\
\hline $5 e^{a)}$ & A & 3 & $\mathrm{~S}$ & $\mathrm{H}$ & $\mathrm{H}$ & 97 & $62 * *$ & $20(37)$ \\
\hline $5 f$ & A & 2 & $\mathrm{NH}$ & $\mathrm{H}$ & $\mathrm{H}$ & 100 & $90 * *$ & $17(40)$ \\
\hline $5 \mathrm{~g}$ & A & 4 & $\mathrm{NH}$ & $\mathrm{H}$ & $\mathrm{H}$ & 98 & $91 * *$ & $28(40)$ \\
\hline $5 \mathbf{h}^{a)}$ & A & 2 & $\mathrm{O}$ & $\mathrm{H}$ & $\mathrm{H}$ & 100 & $38 * *$ & $24(58)$ \\
\hline $\mathbf{5 i}^{a)}$ & A & 4 & $\mathrm{O}$ & $\mathrm{H}$ & $\mathrm{H}$ & 85 & $90 * *$ & $28(35)$ \\
\hline $5 \mathbf{j}$ & A & 3 & $\mathrm{NH}$ & $\mathrm{CH}_{3}$ & $\mathrm{H}$ & 100 & $92 * *$ & $61(58)$ \\
\hline $5 k$ & A & 3 & $\mathrm{O}$ & $\mathrm{CH}_{3}$ & $\mathrm{H}$ & 98 & $91 * *$ & $27(58)$ \\
\hline $5 \mathbf{l}^{a)}$ & A & 3 & $\mathrm{NH}$ & ${ }^{t} \mathrm{Bu}$ & $\mathrm{H}$ & 98 & $73 * *$ & $50(23)$ \\
\hline $5 \mathbf{m}^{a)}$ & A & 3 & $\mathrm{O}$ & ${ }^{t} \mathrm{Bu}$ & $\mathrm{H}$ & 94 & $89 * *$ & $20(23)$ \\
\hline $5 n$ & A & 3 & $\mathrm{NH}$ & $\mathrm{CO}_{2} \mathrm{CH}_{3}$ & $\mathrm{H}$ & 100 & $78^{* *}$ & $64(11)$ \\
\hline
\end{tabular}

a) Fumarate. b) A: 4-(diphenylmethoxy)piperidino, B: 4-(diphenylmethyl)-1-piperazinyl. c) Inhibitory effect on histamine-induced contraction using isolated tracheal strips of guinea pigs. See Experimental section for details. $d$ ) Inhibitory effect on histamine-induced increase in microvascular permeability in the guinea pig skin. See Experimental section for details. The number of animals was 5. Significant difference was obtained by Dunnett's test. $* * p<0.01$ versus control. $e$ ) Inhibitory effect on eosinophil chemotaxis. Guinea pig peritoneal eosinophils were stimulated by LTB $_{4}$. TAK-225 was used as a reference compound and its inhibition rates are in parentheses. See Experimental section for details.

the 6-position revealed that compounds having a nitrogen or oxygen atom as a linker had an increased inhibitory effect on eosinophil chemotaxis (compare $\mathbf{5 a}, \mathbf{5 c}$ and $\mathbf{5 e}$ ). With respect to the length of the carbon chains $(n)$, the propylene group $(n=3)$ had the most potent activity (compare 5a, 5f and 5g; $\mathbf{5 c}, \mathbf{5 h}$ and $\mathbf{5 i}$ ). In the case of the 2 -substituted derivatives $\left(\mathrm{R}^{3}\right)(\mathbf{5} \mathbf{j}-\mathbf{m})$, the compounds having a nitrogen atom as a linker showed stronger activity compared with the compounds having an oxygen atom. The compound with a methoxycarbonyl group at the 2-position (5n) was more active than the compounds having a methyl group (5j) and a tert-butyl group (5l).

The compounds showing sufficient antihistaminic activity and inhibitory effect on eosinophil chemotaxis were evaluated for brain penetrability using an ex vivo binding assay in guinea pigs. The results are listed in Table 2. The compounds not having a substituent at the 2-position (5a, 5c) completely inhibited the ex vivo $\left[{ }^{3} \mathrm{H}\right]$ pyrilamine binding to $\mathrm{H}_{1}$ receptors in both the lung and the cerebral cortex; 5a and $\mathbf{5 c}$ occupied $\mathrm{H}_{1}$ receptors not only in the lung but also in the cerebral cortex. This result suggested that $\mathbf{5 a}$ and $\mathbf{5 c}$ easily permeated the blood-brain barrier (BBB). In the same way, the compounds having a methyl group (5j) or a methoxycarbonyl group (5n) at the 2-position also showed good brain penetrability. However, the introduction of a tert-butyl group (5l) decreased inhibition of the specific binding of $\left[{ }^{3} \mathrm{H}\right]$ pyrilamine to $\mathrm{H}_{1}$ receptors in the cerebral cortex.

It was reported that terfenadine, which has a tert-butyl group similar to $\mathbf{5 l}$, shows cardiotoxicity when administered in overdoses, in patients suffering from a liver disease, or with ketoconazole or macrolide antibiotics. This toxicity is related to an increase in terfenadine plasma levels as a result of an inhibition of metabolism. These problems were solved by introduction of an isobutylic acid group instead of a tertbutyl group. ${ }^{17,18)}$ Although it was not proven that compound
Table 2. Inhibitory Effect on ex Vivo Measured $\left[{ }^{3} \mathrm{H}\right]$ Pyrilamine Binding to $\mathrm{H}_{1}$ Receptors in the Lung and the Cerebral Cortex in Guinea Pigs ${ }^{a)}$

$$
\mathrm{Ph}_{2} \mathrm{CHO}-\mathrm{N}_{\mathrm{Z}} \mathrm{N}_{\mathrm{N}^{-}} \mathrm{N}_{\mathrm{N}}
$$

\begin{tabular}{lllrc}
\hline \hline No. & $\mathrm{Z}$ & \multicolumn{1}{c}{$\mathrm{R}^{3}$} & [Lung] \% inh. & $\begin{array}{c}\text { [Cerebral cortex }] \\
\% \text { inh. }\end{array}$ \\
\hline $\mathbf{5 a}$ & $\mathrm{NH}$ & $\mathrm{H}$ & 103 & 97 \\
$\mathbf{5 c}$ & $\mathrm{O}$ & $\mathrm{H}$ & 78 & 95 \\
$\mathbf{5 j}$ & $\mathrm{NH}$ & $\mathrm{CH}_{3}$ & 104 & 98 \\
$\mathbf{5 1}$ & $\mathrm{NH}$ & ${ }^{t} \mathrm{Bu}$ & 98 & 31 \\
$\mathbf{5 n}$ & $\mathrm{NH}$ & $\mathrm{CO}_{2} \mathrm{CH}_{3}$ & 90 & 86 \\
\hline
\end{tabular}

a) Compounds were administered orally at $100 \mathrm{mg} / \mathrm{kg}$. See Experimental section for details. The number of animals was 3 .

5l has the same side effect, we tried to convert the tert-butyl group into an isobutylic acid group. Additionally, the $[1,2,4]$ triazolo[ $1,5-b]$ pyridazine ring was converted into an imidazo[1,2- $b]$ pyridazine ring because of its synthetic facility, when substituted by an isobutylic acid group.

The results for imidazo[1,2-b]pyridazines (6) are summarized in Table 3. Most of the compounds listed in the table showed in vitro and in vivo antihistaminic activity.

In the eosinophil chemotaxis inhibition assay, compound 6a exhibited the most potent activity, and conversion of a nitrogen atom at the 6-position (6a) into an oxygen (6b) or a sulfur atom (6d) decreased the activity. As for the cyclic amines, the piperazine derivative (6f) and a compound having a hydroxy group (6h) showed less activity than $\mathbf{6 a}$.

Compounds 6a, 6c, 6d, 6e, 6f and $\mathbf{6 n}$, the carboxylic acid derivative of $\mathbf{6 b},{ }^{19)}$ were evaluated for their brain penetrability. As shown in Table 4, the compound having a nitrogen atom as a linker (6a) was found to least effectively penetrate the brain in comparison with the compounds having a meth- 
Table 3. Antihistaminic and Eosinophil Chemotaxis Inhibitory Effects of Imidazo[1,2-b]pyridazine Derivatives

\begin{tabular}{|c|c|c|c|c|c|c|}
\hline \multirow[b]{2}{*}{ No. } & \multirow[b]{2}{*}{$\mathrm{R}^{1} \mathrm{R}^{2} \mathrm{~N}^{d)}$} & \multirow[b]{2}{*}{$\mathrm{Z}$} & \multirow[b]{2}{*}{$\mathrm{R}^{3}$} & \multicolumn{2}{|c|}{ Antihistaminic activities } & \multirow{2}{*}{$\begin{array}{c}\text { Eosinophil } \\
\text { chemotaxis } \\
\text { \% inh. } \\
\left.\text { (at } 10^{-5} \mathrm{M}\right)\end{array}$} \\
\hline & & & & $\begin{array}{l}\mathrm{H}_{1} \text { in vitro }{ }^{e)} \% \text { inh. } \\
\left(\text { at } 10^{-5} \mathrm{M}\right)\end{array}$ & $\begin{array}{c}\mathrm{H}_{1} \text { in vivof) \% inh. } \\
\quad(3 \mathrm{mg} / \mathrm{kg}, \text { p.o. })\end{array}$ & \\
\hline $6 \mathbf{a}^{a)}$ & $\mathrm{A}$ & $\mathrm{NH}$ & $\mathrm{C}\left(\mathrm{CH}_{3}\right)_{2} \mathrm{CO}_{2} \mathrm{C}_{2} \mathrm{H}_{5}$ & 100 & $89 * *$ & $79(8.8)$ \\
\hline $\mathbf{6 b}^{a)}$ & A & $\mathrm{O}$ & $\mathrm{C}\left(\mathrm{CH}_{3}\right)_{2} \mathrm{CO}_{2} \mathrm{C}_{2} \mathrm{H}_{5}$ & 100 & $90^{* *}$ & $31(38)$ \\
\hline $\mathbf{6 c}^{b)}$ & A & $\mathrm{CH}_{2}$ & $\mathrm{C}\left(\mathrm{CH}_{3}\right)_{2} \mathrm{CO}_{2} \mathrm{C}_{2} \mathrm{H}_{5}$ & 96 & $83 * *$ & $45(17)$ \\
\hline $\mathbf{6 d}^{b)}$ & A & $\mathrm{S}$ & $\mathrm{C}\left(\mathrm{CH}_{3}\right)_{2} \mathrm{CO}_{2} \mathrm{CH}_{3}$ & 100 & $92 * *$ & $18(21)$ \\
\hline $\mathbf{6 e}^{b)}$ & $\mathrm{A}$ & $\mathrm{NCH}_{3}$ & $\mathrm{C}\left(\mathrm{CH}_{3}\right)_{2} \mathrm{CO}_{2} \mathrm{C}_{2} \mathrm{H}_{5}$ & 100 & $92 * *$ & $29(15)$ \\
\hline $6 f^{c)}$ & $\mathrm{B}$ & $\mathrm{NH}$ & $\mathrm{C}\left(\mathrm{CH}_{3}\right)_{2} \mathrm{CO}_{2} \mathrm{C}_{2} \mathrm{H}_{5}$ & 94 & $93^{* *}$ & $40(28)$ \\
\hline $\mathbf{6 g}^{a)}$ & $\mathrm{C}$ & NH & $\mathrm{C}\left(\mathrm{CH}_{3}\right)_{2} \mathrm{CO}_{2} \mathrm{C}_{2} \mathrm{H}_{5}$ & 96 & $50^{* *}$ & $78(20)$ \\
\hline $\mathbf{6 h}^{b)}$ & $\mathrm{D}$ & $\mathrm{NH}$ & $\mathrm{C}\left(\mathrm{CH}_{3}\right)_{2} \mathrm{CO}_{2} \mathrm{C}_{2} \mathrm{H}_{5}$ & 100 & $67 * *$ & $49(32)$ \\
\hline $6 \mathbf{i}^{b)}$ & A & $\mathrm{NH}$ & $\searrow \mathrm{CO}_{2} \mathrm{C}_{2} \mathrm{H}_{5}$ & 96 & $87 * *$ & $42(39)$ \\
\hline $\mathbf{6 j}^{b)}$ & $\mathrm{A}$ & $\mathrm{NH}$ & $\nsucc \mathrm{CO}_{2} \mathrm{C}_{2} \mathrm{H}_{5}$ & 87 & 36 & $72(39)$ \\
\hline $6 \mathbf{k}$ & A & $\mathrm{NH}$ & $\mathrm{C}\left(\mathrm{CH}_{3}\right)_{2} \mathrm{CH}_{2} \mathrm{OH}$ & 94 & $92^{* *}$ & $58(58)$ \\
\hline $\mathbf{6 l}^{b)}$ & A & NH & $\mathrm{C}\left(\mathrm{CH}_{3}\right)_{2} \mathrm{CONH}_{2}$ & 92 & 35 & $67(54)$ \\
\hline $6 \mathbf{m}^{b)}$ & A & NH & $\mathrm{C}\left(\mathrm{CH}_{3}\right)_{2} \mathrm{CON}\left(\mathrm{CH}_{3}\right)_{2}$ & 87 & 62 & $54(54)$ \\
\hline
\end{tabular}

a) Difumarate. b) Dihydrochloride. c) Trihydrochloride. d) A: 4-(diphenylmethoxy)piperidino, B: 4-(diphenylmethyl)-1-piperazinyl, C: 4-[bis(4-fluorophenyl)methoxy]piperidino, D: 4-(hydroxydiphenylmethyl)piperidino. $\quad e-g$ ) See the footnote $c-e$ ) of Table 1.

Table 4. Inhibitory Effect on ex Vivo Measured $\left[{ }^{3} \mathrm{H}\right]$ Pyrilamine Binding to $\mathrm{H}_{1}$ Receptors in the Lung and the Cerebral Cortex in Guinea Pigs ${ }^{a)}$

$$
\mathrm{R}^{1} \mathrm{R}^{2} \mathrm{~N}
$$

\begin{tabular}{ccllcc}
\hline \hline No. & $\mathrm{R}^{1} \mathrm{R}^{2} \mathrm{~N}^{b)}$ & $\mathrm{Z}$ & \multicolumn{1}{c}{$\mathrm{R}^{6}$} & $\begin{array}{c}{[\text { Lung }]} \\
\% \text { inh. }\end{array}$ & $\begin{array}{c}\text { [Cerebral } \\
\text { cortex] \% inh. }\end{array}$ \\
\hline $\mathbf{6 a}$ & $\mathrm{A}$ & $\mathrm{NH}$ & $\mathrm{C}_{2} \mathrm{H}_{5}$ & 89 & 30 \\
$\mathbf{6 n}$ & $\mathrm{A}$ & $\mathrm{O}$ & $\mathrm{H}$ & 94 & 82 \\
$\mathbf{6 c}$ & $\mathrm{A}$ & $\mathrm{CH}_{2}$ & $\mathrm{C}_{2} \mathrm{H}_{5}$ & 78 & 42 \\
$\mathbf{6 d}$ & $\mathrm{A}$ & $\mathrm{S}$ & $\mathrm{CH}_{3}$ & 100 & 70 \\
$\mathbf{6 e}$ & $\mathrm{A}$ & $\mathrm{NCH}_{3}$ & $\mathrm{C}_{2} \mathrm{H}_{5}$ & 101 & 57 \\
$\mathbf{6 f}$ & $\mathrm{B}$ & $\mathrm{NH}$ & $\mathrm{C}_{2} \mathrm{H}_{5}$ & 102 & 86 \\
\hline
\end{tabular}

a) See the footnote of Table 2. b) A: 4-(diphenylmethoxy)piperidino, B: 4(diphenylmethyl)-1-piperazinyl.

ylene group (6c), a sulfur atom (6d) and an oxygen atom (6n). Methylation of the amino group of $6 \mathbf{a}(\mathbf{6 e})$ and conversion of the piperidinyl group of $\mathbf{6 a}$ into a piperazinyl group (6f) increased brain penetrability.

Comparison between 6a and Its Metabolite 6o The results of the screening assays revealed that $\mathbf{6 a}$ has a potent inhibitory effect on eosinophil chemotaxis and antihistaminic activity, besides showing little ability to cross of the BBB. Furthermore, a pharmacokinetic study of compound 6 a revealed that it was rapidly metabolized to the carboxylic acid derivative (6o) when orally administered to guinea pigs (data not shown). We compared $\mathbf{6 a}$ and $\mathbf{6 0}$ in terms of antihistaminic activity and the inhibitory effect on eosinophil infiltration.

The in vitro and in vivo antihistaminic activity of compound 60 is shown in Table 5. The compound showed antihistaminic activity in vitro at a concentration of $10^{-5} \mathrm{M}$ and in vivo when administered orally at a dose of $3 \mathrm{mg} / \mathrm{kg}$. Additionally, on oral administration, 60 showed preferential peripheral binding similar to $\mathbf{6 a}$.

The effect of $6 \mathbf{a}$ and 60 on antigen-induced eosinophil in- filtration of the skin was evaluated in sensitized guinea pigs. $^{20)}$ The results are listed in Table 5. Both $6 \mathbf{6}$ and 60 significantly prevented eosinophils from infiltrating the skin at doses of 1 and $10 \mathrm{mg} / \mathrm{kg}$, when administered orally.

Comparison of 60 with Antihistamines and Dexamethasone The antihistaminic activity and inhibitory effect on eosinophil infiltration of $\mathbf{6 0}$ were evaluated and compared with the reference compounds. The results are listed in Table 6.

Compound 60 showed in vitro antihistaminic activity with an $\mathrm{IC}_{50}$ value of $27.1 \mathrm{~nm}$. It was found to be as potent as azelastine, 25-fold less potent than ketotifen, and 13-fold more potent than terfenadine. The in vivo antihistaminic activity of 6o was expressed as the dose required for $50 \%$ inhibition $\left(\mathrm{ID}_{50}\right)$ of the increase in microvascular permeability, which was $0.88 \mathrm{mg} / \mathrm{kg}$ (per os (p.o.)). Azelastine and ketotifen were found to be 20 and 30 -fold more potent than $\mathbf{6 0}$ respectively, however, terfenadine was 1.5 fold less active than $\mathbf{6 0}$.

The results of brain penetrability were expressed in $\mathrm{ID}_{50}$ values, the dose required for $50 \%$ inhibition of $\left[{ }^{3} \mathrm{H}\right]$ pyrilamine binding in the lung $\left(\mathrm{ID}_{50}(\mathrm{~L})\right)$ and the cerebral cortex $\left(\mathrm{ID}_{50}(\mathrm{C})\right)$ of guinea pigs. A selectivity index between $\mathrm{ID}_{50}$ (L) and $\mathrm{ID}_{50}(\mathrm{C})$ is also listed as $\mathrm{C} / \mathrm{L}$. Compound 60 selectively decreased the specific binding of $\left[{ }^{3} \mathrm{H}\right]$ pyrilamine to the lung membrane with an $\mathrm{ID}_{50}$ value of $0.40 \mathrm{mg} / \mathrm{kg}$, while the $\mathrm{ID}_{50}$ (C) value was more than $300 \mathrm{mg} / \mathrm{kg}$. In the case of known antihistamines, the selectivity index of terfenadine recognized as a non-sedative antihistamine showed that it has only a little ability to penetrate into the brain, while azelastine and ketotifen readily permeated the BBB in our experimental model.

The inhibitory effects of terfenadine and dexamethasone on eosinophil infiltration in guinea pigs were examined. Dexamethasone at $10 \mathrm{mg} / \mathrm{kg}$, p.o. potently inhibited the infiltration of the skin. In contrast, terfenadine did not. These results suggested that the inhibition by $\mathbf{6 0}$ of eosinophil infiltration was due to a mechanism unrelated to its antihistaminic effect. 
Table 5. Antihistaminic and Antiinflammatory Activities of $\mathbf{6 a}$ and 60

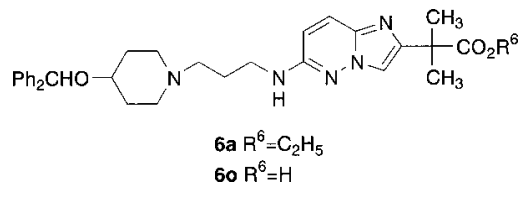

Antihistaminic activities

\begin{tabular}{|c|c|c|c|c|c|c|c|}
\hline \multirow{3}{*}{ No. } & \multirow{3}{*}{$\begin{array}{l}\mathrm{H}_{1} \text { in vitro }{ }^{c)} \\
\% \text { inh. } \\
\left(\text { at } 10^{-5} \mathrm{M}\right)\end{array}$} & & & & & & \\
\hline & & \multirow{2}{*}{$\begin{array}{c}\left.\mathrm{H}_{1} \text { in vivo }{ }^{d}\right) \\
\% \text { inh. } \\
(3 \mathrm{mg} / \mathrm{kg}, \text { p.o. })\end{array}$} & \multicolumn{2}{|c|}{$\begin{array}{c}\mathrm{H}_{1} \text { ex vivo }^{e)} \\
\% \text { inh. }(100 \mathrm{mg} / \mathrm{kg}, \text { p.o. })\end{array}$} & \multicolumn{3}{|c|}{$\begin{array}{l}\text { Number of eoxinophils }{ }^{f)} \\
\% \text { inh. }(\mathrm{mg} / \mathrm{kg}, \text { p.o. })\end{array}$} \\
\hline & & & Lung & Cerebral cortex & 0.1 & 1 & 10 \\
\hline $6 \mathbf{a}^{a)}$ & 100 & $89^{* *}$ & 89 & 30 & 14 & $50 * *$ & $31^{*}$ \\
\hline $6^{b)}$ & 97 & $79 * *$ & 95 & 44 & - & $43^{*}$ & $58 * *$ \\
\hline
\end{tabular}

a) Difumarate. $b$ ) Dihydrate. $c, d$ ) See the footnote of Table 1. e) See the footnote of Table $2 . \quad f$ ) Inhibitory effect on eosinophil infiltration into the dermis. See Experimental section for details. The number of animals was 10. Significant difference was obtained by Dunnett's test. $* p<0.05$ and $* * p<0.01$ versus control.

Table 6. Antihistaminic and Antiinflammatory Activities of 60 (TAK427), Antihistamines and Dexamethasone

\begin{tabular}{|c|c|c|c|c|c|}
\hline & $\begin{array}{c}\mathbf{6 0} \\
(\mathrm{TAK}-427)\end{array}$ & $\mathrm{TER}^{a)}$ & $\mathrm{AZL}^{b)}$ & $\mathrm{KET}^{c}$ & $\mathrm{DEX}^{d)}$ \\
\hline \multicolumn{6}{|l|}{ Antihistaminic activities } \\
\hline \multicolumn{6}{|l|}{ In vitro $o^{e)}$} \\
\hline $\mathrm{IC}_{50}(\mathrm{nM})$ & 27.1 & 350 & 27.6 & 1.06 & \\
\hline \multicolumn{6}{|l|}{ In vivo ${ }^{f)}$} \\
\hline $\mathrm{ID}_{50}(\mathrm{mg} / \mathrm{kg}$, p.o. $)$ & 0.88 & 1.3 & 0.043 & 0.029 & \\
\hline \multicolumn{6}{|l|}{ Ex vivog) } \\
\hline Lung; $\mathrm{ID}_{50}(\mathrm{~L})(\mathrm{mg} / \mathrm{kg}$, p.o. $)$ & 0.40 & 1.5 & 0.024 & 0.003 & \\
\hline $\begin{array}{l}\text { Cerebral cortex; } \mathrm{ID}_{50}(\mathrm{C}) \\
\quad(\mathrm{mg} / \mathrm{kg}, \text { p.o. })\end{array}$ & $>300$ & $>300$ & 0.23 & 0.019 & \\
\hline $\mathrm{C} / \mathrm{L}^{h)}$ & $>740$ & $>200$ & 10 & 6 & \\
\hline \multicolumn{6}{|l|}{ Antiinflammatory activity } \\
\hline \multicolumn{6}{|c|}{ Number of eosinophils, ${ }^{i)} \%$ inh. } \\
\hline $1 \mathrm{mg} / \mathrm{kg}$, p.o. & $43^{*}$ & -5 & & & 15 \\
\hline $10 \mathrm{mg} / \mathrm{kg}$, p.o. & $58^{* *}$ & 2 & & & $65^{* *}$ \\
\hline
\end{tabular}

a) Terfenadine. b) Azelastine. c) Ketotifen. d) Dexamethasone. e) See the footnote of Table $1 . \mathrm{IC}_{50}$ values were obtained from the concentration-inhibition relationships. $f$ ) See the footnote $d$ ) of Table $1 . \mathrm{ID}_{50}$ values were calculated from the dose-inhibition relationships. The number of animals was 6 in each group. $g$ ) See the footnote of Table 2 . ID $\mathrm{ID}_{50}$ values were the doses required for $50 \%$ reduction of ex vivo measured $\left[{ }^{3} \mathrm{H}\right]$ pyrilamine-specific binding to $\mathrm{H}_{1}$ receptors and calculated from the dosebinding relationships. The number of animals was 3 in each group. h) Selectivity index: $\left.\operatorname{ID}_{50}(\mathrm{C}) / \mathrm{ID}_{50}(\mathrm{~L}) . \quad i\right)$ See the footnote $f$ ) of Table 5 .

In conclusion, we synthesized fused pyridazine derivatives having cyclic amines containing a benzhydryl group and evaluated their antihistaminic activity and inhibitory effect on eosinophil infiltration. Among the compounds tested, 60 showed potent activity, and also had reduced brain penetrability as suggested from the results of the ex vivo binding assay. Therefore, compound $\mathbf{6 0}$ (TAK-427) is expected to suppress dermal inflammation and intolerable itching sensations and is a promising drug candidate for the treatment of atopic dermatitis and allergic rhinitis. It is now under clinical investigation.

\section{Experimental}

Melting points $(\mathrm{mp})$ were measured on a Yanagimoto micro melting point apparatus and are uncorrected. IR spectra were recorded on a Shimadzu FTIR-8200PC spectrometer. ${ }^{1} \mathrm{H}-\mathrm{NMR}$ spectra were recorded on a Varian Gemini $200(200 \mathrm{MHz})$ spectrometer, and chemical shifts are given in $\delta$ $(\mathrm{ppm})$ values with tetramethylsilane as an internal standard. The following abbreviations are used: $\mathrm{s}=$ singlet, $\mathrm{d}=$ doublet, $\mathrm{t}=$ triplet, $\mathrm{q}=$ quartet, $\mathrm{m}=$ multiplet and $\mathrm{br} \mathrm{s}=$ broad singlet. Elemental analyses were carried out by Takeda Analytical Research Laboratories, Ltd. The solution in organic solvents was dried over anhydrous magnesium sulfate or sodium sulfate, and evaporation of the organic solvents was carried out under reduced pressure. Column chromatography on silica gel was performed using Kieselgel 60 $(0.063-0.200 \mathrm{~mm}$, Merck).

6-Chloro[1,2,4]triazolo[1,5-b]pyridazine $\quad(\mathbf{1 a}),{ }^{11)}$ 6-chloro-7-isopropyl$[1,2,4]$ triazolo[1,5-b]pyridazine $(\mathbf{1 b}),{ }^{12)}$ 6-chloro-2-methyl[1,2,4]triazolo$[1,5-b]$ pyridazine $\quad(\mathbf{1 c}),{ }^{10)}$ 4-(diphenylmethyl)-1-piperazinepropanamine (3b) ${ }^{21)}$ 4-(diphenylmethoxy)-1-piperidinebutanamine (3f), ${ }^{22)}$ 4-(diphenylmethoxy)piperidine (11a), ${ }^{14)}$ 1-(diphenylmethyl)piperazine (11b) ${ }^{15)}$ 4-(hydroxydiphenylmethyl)piperidine (11d) ${ }^{16)}$ 3-amino-6-chloropyridazine (12), ${ }^{9)}$ ethyl 4-bromo-2,2-dimethyl-3-oxobutyrate (16) ${ }^{13)}$ and azelastine ${ }^{23)}$ were prepared according to procedures described in the literature. Ketotifen, terfenadine and dexamethasone were purchased from Sigma.

$N$-(6-Chloropyridazin-3-yl)- $N^{\prime}$-hydroxy-2,2-dimethylpropanimidamide (14) To a solution of $N, N, 2,2$-tetramethylpropanamide (13) (36.0 g, $279 \mathrm{mmol})$ in toluene $(85 \mathrm{ml})$ was added dropwise phosphorus oxychloride $(18.5 \mathrm{~g}, 121 \mathrm{mmol})$ at $0^{\circ} \mathrm{C}$, and the mixture was stirred at room temperature for $24 \mathrm{~h}$. To this solution, $\mathbf{1 2}(12.0 \mathrm{~g}, 92.6 \mathrm{mmol})$ was added, followed by stirring at $60-70^{\circ} \mathrm{C}$ for $24 \mathrm{~h}$. After cooling, the reaction mixture was diluted with ethyl acetate. The organic layer was washed with $2 \mathrm{~N}$ aqueous solution of sodium hydroxide and brine, dried, and concentrated. The residue was purified by column chromatography on silica gel eluted with hexane-ethyl acetate-triethylamine $(25: 25: 1)$, and the desired fractions were concentrated. The resulting solid was collected by filtration and washed with diethyl ether to give $6.38 \mathrm{~g}$ of $N^{\prime}$-(6-chloropyridazin-3-yl)- $N, N, 2,2$ tetramethylpropanimidamide as colorless crystals. The filtrate concentrated was purified by column chromatography in a similar manner as previously described to give $6.07 \mathrm{~g}$ of the imidamide. A solution of hydroxylamine hydrochloride $(4.31 \mathrm{~g}, 62.0 \mathrm{mmol})$ in methanol $(40 \mathrm{ml})$ was added to a solution of the imidamide $(12.4 \mathrm{~g}, 51.5 \mathrm{mmol})$ in methanol $(60 \mathrm{ml})$, followed by stirring at room temperature for $2 \mathrm{~h}$. After evaporation of half volume of the solvent, the crystalline precipitate was collected by filtration and washed with water and diethyl ether. The organic solvents of the filtrate were evaporated, and the resulting aqueous solution was extracted with ethyl acetate. The combined organic layer was washed with brine, dried, and concentrated. The combined resulting crystals were collected by filtration and washed with diethyl ether to give $10.4 \mathrm{~g}$ of $\mathbf{1 4}\left(49 \%\right.$ yield from $\mathbf{1 2}$ ), mp $128-130^{\circ} \mathrm{C} .{ }^{1} \mathrm{H}-$ NMR (DMSO- $\left.d_{6}\right) \delta: 1.18(9 \mathrm{H}, \mathrm{s}), 6.60(1 \mathrm{H}, \mathrm{d}, J=9.4 \mathrm{~Hz}), 7.51(1 \mathrm{H}, \mathrm{d}$, $J=9.4 \mathrm{~Hz}), 8.77(1 \mathrm{H}, \mathrm{br} \mathrm{s}), 10.60(1 \mathrm{H}, \mathrm{s})$. IR $(\mathrm{KBr}) \mathrm{cm}^{-1}: 3180,2970,1650$, 1590, 1500. Anal. Calcd for $\mathrm{C}_{9} \mathrm{H}_{13} \mathrm{~N}_{4} \mathrm{OCl}: \mathrm{C}, 47.27 ; \mathrm{H}, 5.73 ; \mathrm{N}, 24.50$. Found: C, 47.28; H, 5.59; N, 24.34.

2-tert-Butyl-6-chloro[1,2,4]triazolo[1,5-b]pyridazine (1d) To a suspension of $14(4.07 \mathrm{~g}, 17.8 \mathrm{mmol})$ in chloroform $(170 \mathrm{ml})$ was added dropwise phosphorus oxychloride $(13.6 \mathrm{~g}, 89.0 \mathrm{mmol})$, and the mixture was refluxed for $5 \mathrm{~h}$. After cooling, the reaction mixture was poured into ice-cold aqueous solution of sodium hydroxide. The aqueous solution was separated and extracted with chloroform. The combined organic layer was washed with brine, dried, and concentrated. The residue was purified by column chromatography on silica gel eluted with hexane-ethyl acetate $(5: 1)$, and the desired fractions were concentrated. The resulting solid was recrystallized from hexane-diethyl ether to give $1.12 \mathrm{~g}$ of $\mathbf{1 d}(30 \%$ yield) as light yellow crystals, mp $95-97^{\circ} \mathrm{C} .{ }^{1} \mathrm{H}-\mathrm{NMR}\left(\mathrm{CDCl}_{3}\right) \delta: 1.50(9 \mathrm{H}, \mathrm{s}), 7.39(1 \mathrm{H}, \mathrm{d}$, $J=9.6 \mathrm{~Hz}), 8.04(1 \mathrm{H}, \mathrm{d}, J=9.6 \mathrm{~Hz})$. IR $(\mathrm{KBr}) \mathrm{cm}^{-1}: 2960,1500,1490,1460$. 
Anal. Calcd for $\mathrm{C}_{9} \mathrm{H}_{11} \mathrm{~N}_{4} \mathrm{OCl} \cdot 0.3 \mathrm{H}_{2} \mathrm{O}: \mathrm{C}, 50.03 ; \mathrm{H}, 5.41 ; \mathrm{N}, 25.93$. Found $\mathrm{C}$, $50.23 ; \mathrm{H}, 5.12 ; \mathrm{N}, 25.90$

Methyl 6-Chloro[1,2,4]triazolo[1,5-b]pyridazine-2-carboxylate (1e) To concentrated sulfuric acid $(55 \mathrm{ml})$ was added $1 \mathrm{c}(10.0 \mathrm{~g}, 59.3 \mathrm{mmol})$ at $0{ }^{\circ} \mathrm{C}$ and sodium dichromate dihydrate $(19.4 \mathrm{~g}, 65.3 \mathrm{mmol})$ little by little at the constant temperature, followed by stirring at room temperature for $4 \mathrm{~d}$. After ice-cold water $(200 \mathrm{ml})$ was added to the reaction mixture at $0{ }^{\circ} \mathrm{C}$, the crystals precipitated were collected by filtration, washed with water and diethyl ether, and dried to give $9.74 \mathrm{~g}$ of 6 -chloro[1,2,4]triazolo[1,5-b]pyridazine-2-carboxylic acid ( $83 \%$ yield). To a solution of the carboxylic acid ( $3.02 \mathrm{~g}, 15.2 \mathrm{mmol})$ in $N, N$-dimethylformamide $(50 \mathrm{ml})$ was added $N$-ethyldiisopropylamine $(3.15 \mathrm{ml}, 18.3 \mathrm{mmol})$ and iodomethane $(1.14 \mathrm{ml}, 18.3$ mmol) at $0{ }^{\circ} \mathrm{C}$. After stirring at room temperature for $19 \mathrm{~h}$, ice-cold water and ethyl acetate were added. The crystalline precipitate was collected by filtration and washed with water and diethyl ether. Sodium chloride was added to the filtrate, followed by extraction of THF. The combined organic layer was dried and concentrated. The residue was purified by column chromatography on silica gel eluted with ethyl acetate, and the desired fractions were concentrated. The resulting crystals were washed with diethyl ether and dried to give $2.91 \mathrm{~g}$ of $1 \mathrm{e}\left(90 \%\right.$ yield), mp $208-209^{\circ} \mathrm{C} .{ }^{1} \mathrm{H}-\mathrm{NMR}\left(\mathrm{CDCl}_{3}\right)$ $\delta: 4.10(3 \mathrm{H}, \mathrm{s}), 7.54(1 \mathrm{H}, \mathrm{d}, J=9.4 \mathrm{~Hz}), 8.19(1 \mathrm{H}, \mathrm{d}, J=9.4 \mathrm{~Hz}) . \mathrm{IR}(\mathrm{KBr})$ $\mathrm{cm}^{-1}: 1760,1740$. Anal. Calcd for $\mathrm{C}_{7} \mathrm{H}_{5} \mathrm{~N}_{4} \mathrm{O}_{2} \mathrm{Cl}: \mathrm{C}, 39.55 ; \mathrm{H}, 2.37 ; \mathrm{N}, 26.35$. Found: C, 39.65; H, 2.46; N, 26.34.

Methyl 6-Chloroimidazo[1,2-b]pyridazine-2-acetate (2i) To a suspension of $12(14.0 \mathrm{~g}, 108 \mathrm{mmol})$ in methanol $(130 \mathrm{ml})$ was added methyl 4 chloroacetoacetate (15) $(32.6 \mathrm{~g}, 217 \mathrm{mmol})$, and the mixture was refluxed for $21 \mathrm{~h}$. After cooling, the solvent was evaporated. The residue was adjusted to $\mathrm{pH} 7$ with an aqueous solution of sodium hydrogen carbonate and extracted with diethyl ether. The combined organic layer was washed with brine, dried, and concentrated. The residue was purified by column chromatography on silica gel eluted with hexane-ethyl acetate $(1: 4)$, and the desired fractions were concentrated to give $11.8 \mathrm{~g}$ of $\mathbf{2 i}$ ( $48 \%$ yield) as purple crystals. ${ }^{1} \mathrm{H}$ $\operatorname{NMR}\left(\mathrm{CDCl}_{3}\right) \delta: 3.76(3 \mathrm{H}, \mathrm{s}), 3.91(2 \mathrm{H}, \mathrm{s}), 7.05(1 \mathrm{H}, \mathrm{d}, J=9.2 \mathrm{~Hz}), 7.85$ $(1 \mathrm{H}, \mathrm{d}, J=9.2 \mathrm{~Hz}), 7.94(1 \mathrm{H}, \mathrm{s})$.

Ethyl 1-(6-Chloroimidazo[1,2-b]pyridazin-2-yl)cyclopropanecarboxylate (2a) To a solution of $2 \mathbf{i}(5.93 \mathrm{~g}, 26.3 \mathrm{mmol})$ in $N, N$-dimethylformamide $(45 \mathrm{ml})$ was added sodium hydride $(2.31 \mathrm{~g}, 57.8 \mathrm{mmol} ; 60 \%$ dispersion in oil) at $0{ }^{\circ} \mathrm{C}$, followed by stirring at room temperature for $40 \mathrm{~min} .1,2-$ Dibromoethane $(2.49 \mathrm{ml}, 28.9 \mathrm{mmol})$ was added dropwise at $0{ }^{\circ} \mathrm{C}$, and the mixture was stirred at room temperature for $14 \mathrm{~h}$. The reaction mixture was poured into ice-cold water and extracted with ethyl acetate. The combined organic layer was washed with brine, dried, and concentrated. The residue was purified by column chromatography on silica gel eluted with hexane-ethyl acetate $(2: 1)$, and the desired fractions were concentrated to give $3.67 \mathrm{~g}$ of methyl 1-(6-chloroimidazo[1,2-b]pyridazin-2-yl)cyclopropanecarboxylate $(57 \%$ yield). To a solution of the methyl ester $(4.14 \mathrm{~g}$, $16.5 \mathrm{mmol})$ in ethanol $(80 \mathrm{ml})$ was added slowly concentrated sulfuric acid $(4.03 \mathrm{~g}, 41.1 \mathrm{mmol})$ at room temperature, and the mixture was refluxed for $36 \mathrm{~h}$. After cooling, the solvent was evaporated. The residue was diluted with ice-cold water, neutralized with sodium hydrogen carbonate, and extracted with ethyl acetate. The combined organic layer was washed with brine, dried, and concentrated to give $3.39 \mathrm{~g}$ of $\mathbf{2 b}$ (77\% yield) as crystals. ${ }^{1} \mathrm{H}-\mathrm{NMR}\left(\mathrm{CDCl}_{3}\right) \delta: 1.30(3 \mathrm{H}, \mathrm{t}, J=7.1 \mathrm{~Hz}), 1.63-1.68(2 \mathrm{H}, \mathrm{m}), 1.75$ $1.80(2 \mathrm{H}, \mathrm{m}), 4.23(2 \mathrm{H}, \mathrm{q}, J=7.1 \mathrm{~Hz}), 7.00(1 \mathrm{H}, \mathrm{d}, J=9.1 \mathrm{~Hz}), 7.77(1 \mathrm{H}, \mathrm{d}$, $J=9.1 \mathrm{~Hz}), 8.31(1 \mathrm{H}, \mathrm{s})$. IR $\left(\mathrm{KBr} \mathrm{cm}^{-1}: 3150,3040,2990,1720,1520\right.$.

Ethyl 1-(6-Chloroimidazo[1,2-b]pyridazin-2-yl)cyclopentanecarboxylate (2b) With a similar procedure described for the preparation of $\mathbf{2 a}, \mathbf{2 b}$ was prepared from 2i and 1,4-dibromobutane (57\% yield). ${ }^{1} \mathrm{H}-\mathrm{NMR}$ $\left(\mathrm{CDCl}_{3}\right) \delta: 1.21(3 \mathrm{H}, \mathrm{t}, J=7.1 \mathrm{~Hz}), 1.71-1.80(4 \mathrm{H}, \mathrm{m}), 2.20-2.34(2 \mathrm{H}$, m), 2.46-2.60 (2H, m), $4.16(2 \mathrm{H}, \mathrm{q}, J=7.1 \mathrm{~Hz}), 7.00(1 \mathrm{H}, \mathrm{d}, J=9.6 \mathrm{~Hz})$, $7.84(1 \mathrm{H}, \mathrm{s}), 7.86(1 \mathrm{H}, \mathrm{d}, J=9.6 \mathrm{~Hz})$. IR (KBr) cm ${ }^{-1}: 2960,1730,1520$.

Methyl 2-(6-Chloroimidazo[1,2-b]pyridazin-2-yl)-2-methylpropionate (2c) To a solution of $2 \mathbf{i}(9.15 \mathrm{~g}, 40.5 \mathrm{mmol})$ in $N, N$-dimethylformamide $(70 \mathrm{ml})$ was added sodium hydride $(3.50 \mathrm{~g}, 89.1 \mathrm{mmol} ; 60 \%$ dispersion in oil) at $0{ }^{\circ} \mathrm{C}$, followed by stirring at room temperature for $30 \mathrm{~min}$. Iodomethane $(6.30 \mathrm{ml}, 101 \mathrm{mmol})$ was added dropwise at $0{ }^{\circ} \mathrm{C}$, and the mixture was stirred at $0^{\circ} \mathrm{C}$ for $30 \mathrm{~min}$ and at room temperature for $5 \mathrm{~h}$. The reaction mixture was poured into ice-cold water and extracted with ethyl acetate. The combined organic layer was washed with brine, dried, and concentrated. The residue was purified by column chromatography on silica gel eluted with hexane-ethyl acetate $(1: 1)$, and the desired fractions were concentrated. The resulting crystals were collected by filtration and washed with hexane to give $8.15 \mathrm{~g}$ of $\mathbf{2 c}$ ( $79 \%$ yield), mp $92-93{ }^{\circ} \mathrm{C} .{ }^{1} \mathrm{H}-\mathrm{NMR}\left(\mathrm{CDCl}_{3}\right)$ $\delta: 1.69(6 \mathrm{H}, \mathrm{s}), 3.70(3 \mathrm{H}, \mathrm{s}), 7.03(1 \mathrm{H}, \mathrm{d}, J=9.8 \mathrm{~Hz}), 7.84(1 \mathrm{H}, \mathrm{s}), 7.87(1 \mathrm{H}$, d, $J=9.8 \mathrm{~Hz}$ ). Anal. Calcd for $\mathrm{C}_{11} \mathrm{H}_{12} \mathrm{~N}_{3} \mathrm{O}_{2} \mathrm{Cl}$ : C, $52.08 ; \mathrm{H}, 4.77 ; \mathrm{N}, 16.56$. Found: C, 52.01; H, 4.60; N, 16.59 .

Ethyl 2-(6-Chloroimidazo[1,2-b]pyridazin-2-yl)-2-methylpropionate (2d) A suspension of $\mathbf{1 2}(80.0 \mathrm{~g}, 618 \mathrm{mmol})$, ethyl 4-bromo-2,2-dimethyl3-oxobutyrate (16) $(201 \mathrm{~g}, 848 \mathrm{mmol})$ and disodium hydrogenphosphate $(131 \mathrm{~g}, 923 \mathrm{mmol})$ in ethanol $(300 \mathrm{ml})$ was refluxed for $8 \mathrm{~h}$. After cooling, the reaction mixture was diluted with water and extracted with ethyl acetate. The combined organic layer was washed with water and brine, dried, and concentrated. The residue was purified by column chromatography on silica gel eluted with hexane-ethyl acetate $(1: 1)$, and the desired fractions were concentrated. The residue was crystallized from hexane to give $99.3 \mathrm{~g}$ of $\mathbf{2 d}$ $\left(60 \%\right.$ yield) as crystals, mp $64-65^{\circ} \mathrm{C} .{ }^{1} \mathrm{H}-\mathrm{NMR}\left(\mathrm{CDCl}_{3}\right) \delta: 1.23(3 \mathrm{H}, \mathrm{t}$, $J=7.1 \mathrm{~Hz}), 1.68(6 \mathrm{H}, \mathrm{s}), 4.17(2 \mathrm{H}, \mathrm{q}, J=7.1 \mathrm{~Hz}), 7.02(1 \mathrm{H}, \mathrm{d}, J=9.7 \mathrm{~Hz})$, $7.84(1 \mathrm{H}, \mathrm{s}), 7.87(1 \mathrm{H}, \mathrm{d}, J=9.7 \mathrm{~Hz})$. IR $(\mathrm{KBr}) \mathrm{cm}^{-1}: 2980,1730,1520$. Anal. Calcd for $\mathrm{C}_{12} \mathrm{H}_{14} \mathrm{~N}_{3} \mathrm{O}_{2} \mathrm{Cl}$ : C, 53.84; H, 5.27; N, 15.70. Found: C, $53.85 ; \mathrm{H}, 5.16 ; \mathrm{N}, 15.80$.

2-(6-Chloroimidazo[1,2-b]pyridazin-2-yl)-2-methylpropionic Acid (2j) To a solution of $2 \mathbf{d}(1.00 \mathrm{~g}, 3.74 \mathrm{mmol})$ in tetrahydrofuran $(12 \mathrm{ml})$ was added $1 \mathrm{~N}$ aqueous solution of sodium hydroxide $(4.49 \mathrm{ml}, 4.49 \mathrm{mmol})$, and the mixture was stirred at room temperature for $24 \mathrm{~h}$. After evaporation of tetrahydrofuran, the residue was adjusted to $\mathrm{pH} 6$ with $2 \mathrm{~N}$ hydrochloric acid. The crystalline precipitate was collected by filtration to give $0.303 \mathrm{~g}$ of $\mathbf{2 j}$ (34\% yield) as colorless crystals, mp $159-161{ }^{\circ} \mathrm{C} .{ }^{1} \mathrm{H}-\mathrm{NMR}\left(\mathrm{CDCl}_{3}\right) \delta$ : $1.70(6 \mathrm{H}, \mathrm{s}), 7.12(1 \mathrm{H}, \mathrm{d}, J=9.6 \mathrm{~Hz}), 7.85(1 \mathrm{H}, \mathrm{s}), 7.94(1 \mathrm{H}, \mathrm{d}, J=9.6 \mathrm{~Hz})$. Anal. Calcd for $\mathrm{C}_{10} \mathrm{H}_{10} \mathrm{~N}_{3} \mathrm{O}_{2} \mathrm{Cl}$ : C, 50.12; H, 4.21; N, 17.53. Found: C, $50.36 ; \mathrm{H}, 4.34 ; \mathrm{N}, 17.32$.

tert-Butyl 2-(6-Chloroimidazo[1,2-b]pyridazin-2-yl)-2-methylpropionate (2h) To a suspension of $2 \mathbf{j}(0.863 \mathrm{~g}, 3.60 \mathrm{mmol})$ in toluene $(10 \mathrm{ml})$ was added $N, N$-dimethylformamide di-tert-butylacetal $(2.59 \mathrm{ml}, 10.8 \mathrm{mmol})$, and the mixture was stirred at $80^{\circ} \mathrm{C}$ for $1 \mathrm{~h}$. After cooling, the reaction mixture was diluted with ethyl acetate, washed with an aqueous solution of sodium hydrogen carbonate, dried, and concentrated. The residue was crystallized from diethyl ether to give $0.520 \mathrm{~g}$ of $\mathbf{2 h}$ ( $48 \%$ yield). ${ }^{1} \mathrm{H}-\mathrm{NMR}$ $\left(\mathrm{CDCl}_{3}\right) \delta: 1.43(9 \mathrm{H}, \mathrm{s}), 1.64(6 \mathrm{H}, \mathrm{s}), 7.02(1 \mathrm{H}, \mathrm{d}, J=9.5 \mathrm{~Hz}), 7.84(1 \mathrm{H}, \mathrm{s})$, $7.87(1 \mathrm{H}, \mathrm{d}, J=9.5 \mathrm{~Hz})$.

2-(6-Chloroimidazo[1,2-b]pyridazin-2-yl)-2-methylpropanol (2e) To a solution of $\mathbf{2 j}(0.719 \mathrm{~g}, 3.00 \mathrm{mmol})$ in tetrahydrofuran $(15 \mathrm{ml})$ was added $N, N^{\prime}$-carbonyldiimidazole $(0.535 \mathrm{~g}, 3.30 \mathrm{mmol})$, and the mixture was stirred at room temperature for $1 \mathrm{~h}$. Addition of tetra- $n$-butylammonium borohydride $(1.15 \mathrm{~g}, 4.50 \mathrm{mmol})$ at $0{ }^{\circ} \mathrm{C}$ to the mixture was followed by stirring at room temperature for $1 \mathrm{~h}$. To the reaction mixture was added $5 \mathrm{~N}$ hydrochloric acid $(2 \mathrm{ml})$, and the organic solvent was evaporated. The resulting aqueous residue was adjusted to $\mathrm{pH} 7$ with an aqueous solution of sodium hydrogen carbonate and extracted with ethyl acetate. The combined organic layer was washed with brine, dried, and concentrated. The residue was purified by column chromatography on silica gel eluted with ethyl acetate, and the desired fractions were concentrated to give $0.488 \mathrm{~g}$ of $2 \mathrm{e}$ ( $72 \%$ yield) as crystals. ${ }^{1} \mathrm{H}-\mathrm{NMR}\left(\mathrm{CDCl}_{3}\right) \delta: 1.39(6 \mathrm{H}, \mathrm{s}), 3.72(2 \mathrm{H}, \mathrm{s}), 7.04(1 \mathrm{H}, \mathrm{d}, J=9.5 \mathrm{~Hz})$, $7.76(1 \mathrm{H}, \mathrm{s}), 7.82(1 \mathrm{H}, \mathrm{d}, J=9.5 \mathrm{~Hz})$

2-(6-Chloroimidazo[1,2-b]pyridazin-2-yl)-2-methylpropionamide (2f) To a solution of $\mathbf{2 j}(1.20 \mathrm{~g}, 5.00 \mathrm{mmol})$ in $N, N$-dimethylformamide $(8 \mathrm{ml})$ was added $N, N^{\prime}$-carbonyldiimidazole $(0.892 \mathrm{~g}, 5.50 \mathrm{mmol})$, and the mixture was stirred at room temperature for $30 \mathrm{~min}$. To the mixture were added ammonium chloride $(0.321 \mathrm{~g}, 6.00 \mathrm{mmol})$ and triethylamine $(0.832 \mathrm{ml}$, $6.00 \mathrm{mmol}$ ) at $0{ }^{\circ} \mathrm{C}$, followed by stirring at room temperature for $3 \mathrm{~h}$. After addition of ice-cold water to the reaction mixture, the crystalline precipitate was collected by filtration, washed with water, and dried to give $0.697 \mathrm{~g}$ of 2f. The filtrate was extracted with ethyl acetate, and the combined organic layer was washed with brine, dried, and concentrated. The resulting crystals were collected by filtration, washed with diethyl ether to give $0.229 \mathrm{~g}$ of $\mathbf{2 f}$ (total: $83 \%$ yield), mp $194-195{ }^{\circ} \mathrm{C} .{ }^{1} \mathrm{H}-\mathrm{NMR}\left(\mathrm{CDCl}_{3}\right) \delta: 1.68(6 \mathrm{H}, \mathrm{s}), 5.46$ $(1 \mathrm{H}, \mathrm{br} \mathrm{s}), 7.08(1 \mathrm{H}, \mathrm{d}, J=9.5 \mathrm{~Hz}), 7.10(1 \mathrm{H}, \mathrm{br} \mathrm{s}), 7.76(1 \mathrm{H}, \mathrm{s}), 7.82(1 \mathrm{H}, \mathrm{d}$, $J=9.5 \mathrm{~Hz})$. Anal. Calcd for $\mathrm{C}_{10} \mathrm{H}_{11} \mathrm{~N}_{4} \mathrm{OCl}: \mathrm{C}, 50.32 ; \mathrm{H}, 4.65 ; \mathrm{N}, 23.47$. Found: C, 50.34; H, 4.60; N, 23.43 .

2-(6-Chloroimidazo[1,2-b]pyridazin-2-yl)- $N, N, 2$-trimethylpropionamide (2g) To a solution of $\mathbf{2 j}(0.959 \mathrm{~g}, 4.00 \mathrm{mmol})$ in $N, N$-dimethylformamide $(6 \mathrm{ml})$ was added $N, N^{\prime}$-carbonyldiimidazole $(0.714 \mathrm{~g}, 4.40 \mathrm{mmol})$, and the mixture was stirred at room temperature for $1 \mathrm{~h}$. To the mixture were added dimethylamine hydrochloride $(0.392 \mathrm{~g}, 4.80 \mathrm{mmol})$ and triethylamine $(0.665 \mathrm{ml}, 4.80 \mathrm{mmol})$ at $0{ }^{\circ} \mathrm{C}$, followed by stirring at room temperature for $3 \mathrm{~h}$. The reaction mixture was diluted with brine and extracted with ethyl acetate. The combined organic layer was washed with brine, dried, and concentrated. The residue was purified by column chromatography on silica gel eluted with ethyl acetate-methanol $(19: 1)$, and the desired fractions were 
concentrated. The resulting crystals were collected by filtration to give $0.608 \mathrm{~g}$ of $2 \mathrm{~g}(57 \%$ yield $), \mathrm{mp} 149-151^{\circ} \mathrm{C} .{ }^{1} \mathrm{H}-\mathrm{NMR}\left(\mathrm{CDCl}_{3}\right) \delta: 1.66(6 \mathrm{H}$, s), $2.78(6 \mathrm{H}, \mathrm{s}), 7.05(1 \mathrm{H}, \mathrm{d}, J=9.5 \mathrm{~Hz}), 7.74(1 \mathrm{H} \mathrm{s}), 7.88(1 \mathrm{H}, \mathrm{d}, J=9.5 \mathrm{~Hz})$. Anal. Calcd for $\mathrm{C}_{12} \mathrm{H}_{15} \mathrm{~N}_{4} \mathrm{OCl}$ : C, 54.04; H, 5.67; N, 21.01. Found: C, 53.90; $\mathrm{H}, 5.85 ; \mathrm{N}, 21.04$.

4-[Bis(4-fluorophenyl)methoxy]-1-piperidinepropanamine (3c) To a solution of $4,4^{\prime}$-difluorobenzophenone $(25.0 \mathrm{~g}, 114 \mathrm{mmol})$ in ethanoltetrahydrofuran $(180-60 \mathrm{ml})$ was added sodium borohydride $(2.16 \mathrm{~g}$, $57.0 \mathrm{mmol}$ ) at $0{ }^{\circ} \mathrm{C}$, and the mixture was stirred at room temperature for $30 \mathrm{~min}$. After evaporation of the solvents, the residue was diluted with icecold water and extracted with ethyl acetate. The combined organic layer was washed with brine, dried, and concentrated to give $29.2 \mathrm{~g}$ of bis(4-fluorophenyl)methanol as an oil. To a solution of the alcohol in toluene $(800 \mathrm{ml})$ were added 4-hydroxypiperidine $(11.6 \mathrm{~g}, 114 \mathrm{mmol})$ and $p$-toluenesulfonic acid monohydrate $(23.7 \mathrm{~g}, 125 \mathrm{mmol})$, and the mixture was refluxed with Dean-Stark for $2 \mathrm{~h}$. After cooling and evaporation of the solvent, the residue was diluted with ice-cold water and $1 \mathrm{~N}$ aqueous solution of sodium hydroxide $(130 \mathrm{ml})$ and extracted with ethyl acetate. The combined organic layer was washed with brine, dried, and concentrated to give $34.5 \mathrm{~g}$ of 4-[bis(4fluorophenyl)methoxy]piperidine (11c, crude, quantitative yield (from the benzophenone)). To a solution of the piperidine ( $23.0 \mathrm{~g}$, equivalent to 76.0 mmol) and $\mathrm{N}$-(3-bromopropyl)phthalimide (17) $(16.3 \mathrm{~g}, 60.8 \mathrm{mmol})$ in $\mathrm{N}, \mathrm{N}$ dimethylformamide $(100 \mathrm{ml})$ was added potassium carbonate $(10.5 \mathrm{~g}$, $76.0 \mathrm{mmol}$ ), and the mixture was stirred at room temperature for $20 \mathrm{~h}$. The reaction mixture was diluted with ice-cold water and extracted with ethyl acetate. The combined organic layer was washed with brine, dried, and concentrated. The residue was purified by column chromatography on silica gel eluted with hexane-ethyl acetate $(1: 2)$, and the desired fractions were concentrated to give $20.5 \mathrm{~g}$ of $\mathrm{N}$-[3-[4-[bis(4-fluorophenyl)methoxy]piperidino]propyl]phthalimide (18c) (68\% yield (from 17)) as an oil. To a solution of 18c $(20.5 \mathrm{~g}, 41.7 \mathrm{mmol})$ in ethanol $(150 \mathrm{ml})$ was added hydrazine monohydrate $(2.02 \mathrm{ml}, 41.6 \mathrm{mmol})$, and the mixture was refluxed for $3 \mathrm{~h}$. After cooling and evaporating of the solvent, ethanol was added to the residue. The crystalline precipitate was collected, dissolved in $1 \mathrm{~N}$ aqueous solution of sodium hydroxide $(40 \mathrm{ml})$, and extracted with ethyl acetate-tetrahydrofuran $(2: 1)$. The combined organic layer was washed with brine, dried, and concentrated to give $12.1 \mathrm{~g}$ of $\mathbf{3 c}$ ( $75 \%$ yield) as an oil. ${ }^{1} \mathrm{H}-\mathrm{NMR}\left(\mathrm{CDCl}_{3}\right) \delta$ : $1.55-1.96(6 \mathrm{H}, \mathrm{m}), 2.04-2.18(2 \mathrm{H}, \mathrm{m}), 2.36(2 \mathrm{H}, \mathrm{t}, J=5.8 \mathrm{~Hz}), 2.66-$ $2.80(2 \mathrm{H}, \mathrm{m}), 2.74(2 \mathrm{H}, \mathrm{t}, J=6.8 \mathrm{~Hz}), 3.32-3.45(1 \mathrm{H}, \mathrm{m}), 5.47(1 \mathrm{H}, \mathrm{s})$, $6.94-7.35(8 \mathrm{H}, \mathrm{m})$.

The following compounds, $\mathbf{3 a}$ and $\mathbf{3 d}$, were prepared with a similar procedure described for the preparation of $\mathbf{3 c}$.

4-(Diphenylmethoxy)-1-piperidinepropanamine (3a) From 11a was prepared 3a (57\% yield) as crystals, $\mathrm{mp} 41-43{ }^{\circ} \mathrm{C}$ (from hexane). ${ }^{1} \mathrm{H}-\mathrm{NMR}$ $\left(\mathrm{CDCl}_{3}\right) \delta: 1.62-1.98(6 \mathrm{H}, \mathrm{m}), 2.08-2.24(2 \mathrm{H}, \mathrm{m}), 2.41(2 \mathrm{H}, \mathrm{t}$, $J=7.0 \mathrm{~Hz}), 2.60-3.00(4 \mathrm{H}, \mathrm{m}), 3.38-3.52(1 \mathrm{H}, \mathrm{m}), 5.51(1 \mathrm{H}, \mathrm{s}), 7.20-$ $7.38(10 \mathrm{H}, \mathrm{m})$. IR (KBr) cm ${ }^{-1}: 3280,2940,1570,1490,1450$.

4-(Hydroxydiphenylmethyl)-1-piperidinepropanamine (3d) From $11 \mathbf{d}$ was prepared $3 \mathbf{d}\left(86 \%\right.$ yield) as an oil. ${ }^{1} \mathrm{H}-\mathrm{NMR}\left(\mathrm{CDCl}_{3}\right) \delta: 1.44-1.69$ $(4 \mathrm{H}, \mathrm{m}), 1.79-2.00(6 \mathrm{H}, \mathrm{m}), 2.34-2.52(1 \mathrm{H}, \mathrm{m}), 2.37(2 \mathrm{H}, \mathrm{t}, J=7.4 \mathrm{~Hz})$, $2.73(2 \mathrm{H}, \mathrm{t}, J=6.8 \mathrm{~Hz}), 3.71-3.78(1 \mathrm{H}, \mathrm{m}), 7.10-7.35(6 \mathrm{H}, \mathrm{m}), 7.45-$ $7.52(4 \mathrm{H}, \mathrm{m})$.

$N$-[3-[4-(Diphenylmethoxy)piperidino]propyl]methylamine (3e) To a suspension of $3 \mathrm{a}(0.370 \mathrm{~g}, 1.14 \mathrm{mmol})$ and sodium hydrogen carbonate $(0.109 \mathrm{~g}, 1.30 \mathrm{mmol})$ in tetrahydrofuran $(3 \mathrm{ml})$ was added methyl chloroformate $(0.10 \mathrm{ml}, 1.30 \mathrm{mmol})$, and the mixture was stirred at room temperature for $30 \mathrm{~min}$. The reaction mixture was diluted with ice-cold water and extracted with ethyl acetate. The combined organic layer was washed with brine, dried, and concentrated. The residue was dissolved in tetrahydrofuran $(4 \mathrm{ml})$, followed by addition of lithium aluminum hydride $(0.065 \mathrm{~g}, 1.71$ $\mathrm{mmol})$ at $0{ }^{\circ} \mathrm{C}$. The mixture was stirred for a few minutes under the same conditions and at $60^{\circ} \mathrm{C}$ for $1 \mathrm{~h}$. After cooling, the reaction mixture was quenched with diethyl ether saturated with water, and then water was added to the mixture. The solid precipitated was removed by filtration, and the filtrate was concentrated to give $0.360 \mathrm{~g}$ of $\mathbf{3 e}\left(93 \%\right.$ yield) as an oil. ${ }^{1} \mathrm{H}-\mathrm{NMR}$ $\left(\mathrm{CDCl}_{3}\right) \delta: 1.60-2.00(6 \mathrm{H}, \mathrm{m}), 2.19-2.22(2 \mathrm{H}, \mathrm{m}), 2.36(2 \mathrm{H}, \mathrm{t}, J=7.5$ $\mathrm{Hz}), 2.41(3 \mathrm{H}, \mathrm{s}), 2.60(2 \mathrm{H}, \mathrm{t}, J=6.7 \mathrm{~Hz}), 2.64-2.82(2 \mathrm{H}, \mathrm{m}), 3.38-3.50$ $(1 \mathrm{H}, \mathrm{m}), 5.52(1 \mathrm{H}, \mathrm{s}), 7.21-7.36(10 \mathrm{H}, \mathrm{m})$.

4-(Diphenylmethoxy)-1-piperidinepropanol (4a) To a solution of 11a $(1.61 \mathrm{~g}, 6.02 \mathrm{mmol})$ in $N, N$-dimethylformamide $(30 \mathrm{ml})$ were added 3-bromopropanol $(0.82 \mathrm{ml}, 9.03 \mathrm{mmol})$ and potassium carbonate $(1.66 \mathrm{~g}, 12.0$ $\mathrm{mmol}$ ), and the mixture was stirred at room temperature for $15 \mathrm{~h}$. The reaction mixture was diluted with ice-cold water and extracted with ethyl acetate. The combined organic layer was washed with brine, dried, and concen- trated. The residue was purified by column chromatography on silica gel eluted with ethyl acetate-methanol-triethylamine $(90: 10: 1)$, and the desired fractions were concentrated to give $1.52 \mathrm{~g}$ of $4 \mathrm{a}$ ( $78 \%$ yield) as crystals, mp $62-64^{\circ} \mathrm{C}$ (from hexane-diethyl ether). ${ }^{1} \mathrm{H}-\mathrm{NMR}\left(\mathrm{CDCl}_{3}\right) \delta$ : $1.60-1.96(6 \mathrm{H}, \mathrm{m}), 2.10-2.32(2 \mathrm{H}, \mathrm{m}), 2.58(2 \mathrm{H}, \mathrm{t}, J=5.6 \mathrm{~Hz}), 2.74$ $2.90(2 \mathrm{H}, \mathrm{m}), 3.38-3.55(1 \mathrm{H}, \mathrm{m}), 3.79(2 \mathrm{H}, \mathrm{t}, J=5.1 \mathrm{~Hz}), 5.50(1 \mathrm{H}, \mathrm{s})$, $7.20-7.46(10 \mathrm{H}, \mathrm{m}) . \mathrm{IR}(\mathrm{KBr}) \mathrm{cm}^{-1}: 2940,2820,1490,1450$.

4-(Diphenylmethoxy)-1-piperidineethanol (4b) With a similar procedure described for the preparation of $\mathbf{4 a}, \mathbf{4 b}$ was prepared from 11a and 2bromoethanol (66\% yield) as crystals. ${ }^{1} \mathrm{H}-\mathrm{NMR}\left(\mathrm{CDCl}_{3}\right) \delta: 1.62-1.96(4 \mathrm{H}$, $\mathrm{m}), 2.14-2.30(2 \mathrm{H}, \mathrm{m}), 2.50(2 \mathrm{H}, \mathrm{t}, J=5.4 \mathrm{~Hz}), 2.72-2.84(2 \mathrm{H}, \mathrm{m}), 3.40-$ $3.54(1 \mathrm{H}, \mathrm{m}), 3.57(2 \mathrm{H}, \mathrm{t}, J=5.4 \mathrm{~Hz}), 5.52(1 \mathrm{H}, \mathrm{s}), 7.21-7.37(10 \mathrm{H}, \mathrm{m})$. IR $(\mathrm{KBr}) \mathrm{cm}^{-1}: 3330,2940,2820,1490,1450$.

4-(Diphenylmethoxy)-1-piperidinebutanol (4c) To a solution of 11a $(1.05 \mathrm{~g}, 3.93 \mathrm{mmol})$ in $N, N$-dimethylformamide $(10 \mathrm{ml})$ were added 4-bromobutyl acetate $(0.57 \mathrm{ml}, 3.93 \mathrm{mmol})$ and potassium carbonate $(0.652 \mathrm{~g}$, $4.72 \mathrm{mmol}$ ), and the mixture was stirred at $50^{\circ} \mathrm{C}$ for $3 \mathrm{~h}$. After cooling, the reaction mixture was diluted with ice-cold water and extracted with ethyl acetate. The combined organic layer was washed with brine, dried, and concentrated. The residue was dissolved in ethanol $(15 \mathrm{ml})$, and addition of $1 \mathrm{~N}$ aqueous solution of sodium hydroxide $(8 \mathrm{ml})$ to the solution was followed by stirring at room temperature for $30 \mathrm{~min}$. After evaporation of the solvent, the aqueous residue was neutralized with $1 \mathrm{~N}$ hydrochloric acid and extracted with ethyl acetate. The combined organic layer was washed with brine, dried, and concentrated. The resulting crystals were collected, washed with diethyl ether, and dried to give $1.21 \mathrm{~g}$ of $4 \mathbf{c}\left(91 \%\right.$ yield), $\mathrm{mp} 176-178^{\circ} \mathrm{C}$. ${ }^{1} \mathrm{H}-\mathrm{NMR}\left(\mathrm{CDCl}_{3}\right) \delta: 1.62-1.75(2 \mathrm{H}, \mathrm{m}), 1.90-2.10(4 \mathrm{H}, \mathrm{m}), 2.24-2.46$ $(2 \mathrm{H}, \mathrm{m}), 2.92-3.25(6 \mathrm{H}, \mathrm{m}), 3.74(2 \mathrm{H}, \mathrm{t}, J=5.5 \mathrm{~Hz}), 3.75-3.85(1 \mathrm{H}, \mathrm{m})$, $5.43(1 \mathrm{H}, \mathrm{s}), 7.30-7.40(10 \mathrm{H}, \mathrm{m})$. IR $(\mathrm{KBr}) \mathrm{cm}^{-1}: 3330,2930,2650,1450$.

3-[([1,2,4]Triazolo[1,5-b]pyridazin-6-yl)amino]propanol (10b) To a solution of 1a $(0.928 \mathrm{~g}, 6.00 \mathrm{mmol})$ in ethanol $(10 \mathrm{ml})$ was added 3-amino-1propanol $(7 \mathbf{b})(1.23 \mathrm{~g}, 15.0 \mathrm{mmol})$, and the mixture was refluxed for $3 \mathrm{~h}$. After cooling, the solvent was evaporated to half volume. The resulting crystals were collected, washed with ethanol, and dried to give $0.835 \mathrm{~g}$ of $\mathbf{1 0 b}$ (72\% yield), mp $193-194{ }^{\circ} \mathrm{C} .{ }^{1} \mathrm{H}-\mathrm{NMR}$ (DMSO- $\left.d_{6}\right) \delta: 1.87(2 \mathrm{H}, \mathrm{m}), 3.46$ $(2 \mathrm{H}, \mathrm{m}), 3.67(2 \mathrm{H}, \mathrm{m}), 4.31(1 \mathrm{H}, \mathrm{t}, J=5.2 \mathrm{~Hz}), 6.85(1 \mathrm{H}, \mathrm{t}, J=6.0 \mathrm{~Hz}), 6.97$ $(1 \mathrm{H}, \mathrm{d}, J=9.6 \mathrm{~Hz}), 7.70(1 \mathrm{H}, \mathrm{d}, J=9.6 \mathrm{~Hz}), 8.07(1 \mathrm{H}, \mathrm{s})$. Anal. Calcd for $\mathrm{C}_{8} \mathrm{H}_{11} \mathrm{~N}_{5} \mathrm{O}: \mathrm{C}, 49.73 ; \mathrm{H}, 5.74 ; \mathrm{N}, 36.25$. Found: C, 49.70; H, 5.53; N, 36.28.

2-I([1,2,4]Triazolo[1,5-b]pyridazin-6-yl)amino]ethanol (10a) With a similar procedure described for the preparation of $\mathbf{1 0 b}, \mathbf{1 0 a}$ was prepared from 1a and 2-aminoethanol (7a) $\left(63 \%\right.$ yield) as crystals, mp $219-221{ }^{\circ} \mathrm{C}$ (from ethanol). ${ }^{1} \mathrm{H}-\mathrm{NMR}$ (DMSO- $\left.d_{6}\right) \delta: 3.28-3.37(2 \mathrm{H}, \mathrm{m}), 3.57-3.65$ $(2 \mathrm{H}, \mathrm{m}), 4.80(1 \mathrm{H}, \mathrm{t}, J=5.5 \mathrm{~Hz}), 7.05(1 \mathrm{H}, \mathrm{d}, J=9.7 \mathrm{~Hz}), 7.35(1 \mathrm{H}, \mathrm{t}$, $J=5.5 \mathrm{~Hz}), 7.92(1 \mathrm{H}, \mathrm{d}, J=9.7 \mathrm{~Hz}), 8.19(1 \mathrm{H}, \mathrm{s}) . \mathrm{IR}(\mathrm{KBr}) \mathrm{cm}^{-1}: 3290$, 3250, 2900, 1630, 1590, 1500, 1470. Anal. Calcd for $\mathrm{C}_{7} \mathrm{H}_{9} \mathrm{~N}_{5} \mathrm{O}: \mathrm{C}, 46.92 ; \mathrm{H}$, $5.06 ; \mathrm{N}, 39.09$. Found: C, 46.67; H, 5.00; N, 38.93.

6-(3-Bromopropylthio) $[1,2,4]$ triazolo[1,5-b]pyridazine (10c) To a solution of ethyl 3 -mercaptopropionate $(3.90 \mathrm{ml}, 35.0 \mathrm{mmol})$ in methanol $(40 \mathrm{ml})$ were added $2 \mathrm{~N}$ methanol solution of sodium methoxide $(15 \mathrm{ml}$, $30.0 \mathrm{mmol})$ and $1 \mathrm{a}(1.55 \mathrm{~g}, 10.0 \mathrm{mmol})$, and the mixture was refluxed for $1 \mathrm{~h}$. After cooling, the solvent was evaporated, and ethyl acetate was added to the residue. The resulting solid was collected, washed with ethyl acetate, and suspended in tetrahydrofuran $(40 \mathrm{ml})$. To the suspension was added 1,3-dibromopropane (8a) $(3.06 \mathrm{ml}, 30.0 \mathrm{mmol})$, the mixture was refluxed for $2 \mathrm{~h}$. After cooling, the reaction mixture was diluted with ice-cold water and extracted with ethyl acetate. The combined organic layer was washed with brine, dried, and concentrated. To the residue was added ethyl acetate, and the crystalline precipitate was collected and dried to give $1.97 \mathrm{~g}$ of $10 \mathrm{c}(72 \%$ yield), mp $133-135^{\circ} \mathrm{C} .{ }^{1} \mathrm{H}-\mathrm{NMR}\left(\mathrm{CDCl}_{3}\right) \delta: 2.33-2.46(2 \mathrm{H}, \mathrm{m}), 3.46$ $(2 \mathrm{H}, \mathrm{t}, J=6.6 \mathrm{~Hz}), 3.58(2 \mathrm{H}, \mathrm{t}, J=6.6 \mathrm{~Hz}),, 7.21(1 \mathrm{H}, \mathrm{d}, J=9.4 \mathrm{~Hz}), 7.93$ $(1 \mathrm{H}, \mathrm{d}, J=9.4 \mathrm{~Hz}), 8.37(1 \mathrm{H}, \mathrm{s})$. IR $(\mathrm{KBr}) \mathrm{cm}^{-1}: 3080,1800,1540,1460$. Anal. Calcd for $\mathrm{C}_{8} \mathrm{H}_{9} \mathrm{~N}_{4} \mathrm{SBr}$ : C, 35.18; H, 3.32; N, 20.51. Found: C, 35.11; H, 3.13; N, 20.43.

Methyl 2-[6-(3-Chloropropylthio)imidazo[1,2-b]pyridazin-2-yl]-2methylpropionate (10d) With a similar procedure described for the preparation of $\mathbf{1 0 c}, \mathbf{1 0 d}$ was prepared from $\mathbf{2 d}$ and 1-bromo-3-chloropropane $(\mathbf{8 b})$ (with $28 \%$ methanol solution of sodium methoxide) (35\% yield) as an oil. ${ }^{1} \mathrm{H}-\mathrm{NMR}$ (DMSO- $\left.d_{6}\right) \delta: 1.68(6 \mathrm{H}, \mathrm{s}), 2.20-2.33(2 \mathrm{H}, \mathrm{m}), 3.34(2 \mathrm{H}, \mathrm{t}$, $J=6.9 \mathrm{~Hz}), 3.70(3 \mathrm{H}, \mathrm{s}), 3.71(2 \mathrm{H}, \mathrm{t}, J=6.2 \mathrm{~Hz}), 6.82(1 \mathrm{H}, \mathrm{d}, J=9.4 \mathrm{~Hz})$, $7.70(1 \mathrm{H}, \mathrm{d}, J=9.4 \mathrm{~Hz}), 7.77(1 \mathrm{H}, \mathrm{s})$.

Ethyl 2-[6-(4-Chlorobutyl)imidazo[1,2-b]pyridazin-2-yl]-2-methylpropionate (10e) To a solution of 1-chloro-4-iodobutane (9) $(5.00 \mathrm{~g}$, $22.9 \mathrm{mmol})$ in toluene- $N, N$-dimethylacetamide $(50-5 \mathrm{ml})$ was added zinccopper couple $(2.24 \mathrm{~g}, 34.2 \mathrm{mmol}),{ }^{8}$ and the mixture was stirred at $80^{\circ} \mathrm{C}$ 
under a nitrogen atmosphere for $3.5 \mathrm{~h}$. After cooling, $2 \mathbf{d}(3.06 \mathrm{~g}, 11.4 \mathrm{mmol})$ and dichlorobis(triphenylphosphine)palladium(II) $(0.160 \mathrm{~g}, 0.228 \mathrm{mmol})$ were added to the reaction mixture, and the mixture was stirred at $80^{\circ} \mathrm{C}$ for $4 \mathrm{~h}$. After cooling, the reaction mixture was diluted with water and ethyl acetate, and the insoluble material was filtered off through Celite ${ }^{\circledR}$. The organic layer was separated, washed with brine, dried, and concentrated. The residue was purified by column chromatography on silica gel eluted with hexaneethyl acetate $(1: 1)$, and the desired fractions were concentrated to give $1.74 \mathrm{~g}$ of $10 \mathrm{e}\left(47 \%\right.$ yield) as an oil. ${ }^{1} \mathrm{H}-\mathrm{NMR}\left(\mathrm{CDCl}_{3}\right) \delta: 1.23(3 \mathrm{H}, \mathrm{t}$, $J=7.0 \mathrm{~Hz}), 1.68(6 \mathrm{H}, \mathrm{s}), 1.80-2.20(4 \mathrm{H}, \mathrm{m}), 2.84(2 \mathrm{H}, \mathrm{t}, J=7.2 \mathrm{~Hz}), 3.59$ $(2 \mathrm{H}, \mathrm{t}, J=6.0 \mathrm{~Hz}), 4.17(2 \mathrm{H}, \mathrm{q}, J=7.0 \mathrm{~Hz}), 6.89(1 \mathrm{H}, \mathrm{d}, J=9.4 \mathrm{~Hz}), 7.80$ $(1 \mathrm{H}, \mathrm{s}), 7.81(1 \mathrm{H}, \mathrm{d}, J=9.4 \mathrm{~Hz})$.

6-[[3-[4-(Diphenylmethoxy)piperidino]propyl] amino][1,2,4]triazolo[1,5-b]pyridazine (5a) To a suspension of $10 \mathrm{~b}(0.290 \mathrm{~g}, 1.50 \mathrm{mmol})$ in tetrahydrofuran $(10 \mathrm{ml})$ were added $N$-ethyldiisopropylamine $(0.338 \mathrm{~g}$, $3.00 \mathrm{mmol})$ and methanesulfonyl chloride $(0.334 \mathrm{~g}, 3.00 \mathrm{mmol})$, and the mixture was stirred at room temperature for $1 \mathrm{~h}$. The reaction mixture was diluted with ice-cold brine and extracted with ethyl acetate. The combined organic layer was washed with brine, dried, and concentrated to give $0.320 \mathrm{~g}$ of 6-[[(3-(methylsulfonyloxy)propyl)amino][1,2,4]triazolo[1,5-b]pyridazine (78\% yield). The methylsulfonyloxy derivative $(0.315 \mathrm{~g}, 1.16 \mathrm{mmol})$ was dissolved in $N, N$-dimethylformamide $(5 \mathrm{ml})$, followed by addition of $\mathbf{1 1 a}$ $(0.352 \mathrm{~g}, 1.39 \mathrm{mmol})$, sodium iodide $(0.208 \mathrm{~g}, 1.39 \mathrm{mmol})$ and potassium carbonate $(0.193 \mathrm{~g}, 1.39 \mathrm{mmol})$. The mixture was stirred at room temperature for $15 \mathrm{~h}$ and at $60^{\circ} \mathrm{C}$ for $3 \mathrm{~h}$. After cooling, the reaction mixture was diluted with ice-cold water and extracted with ethyl acetate. The combined organic layer was washed with brine, dried, and concentrated. The residue was purified by column chromatography on silica gel eluted with ethyl acetate-methanol-triethylamine $(90: 10: 1)$, and the desired fractions were concentrated. The resulting crystals were washed with diethyl ether and dried to give $0.209 \mathrm{~g}$ of $\mathbf{5 a}$ ( $40 \%$ yield), mp $136-138^{\circ} \mathrm{C}$. ${ }^{1} \mathrm{H}-\mathrm{NMR}$ (DMSO$\left.d_{6}\right) \delta: 1.46-2.12(8 \mathrm{H}, \mathrm{m}), 2.32-2.40(2 \mathrm{H}, \mathrm{m}), 2.63-2.78(2 \mathrm{H}, \mathrm{m}), 3.20-$ $3.40(3 \mathrm{H}, \mathrm{m}), 5.63(1 \mathrm{H}, \mathrm{s}), 6.98(1 \mathrm{H}, \mathrm{d}, J=9.7 \mathrm{~Hz}), 7.19-7.42(10 \mathrm{H}, \mathrm{m})$, $7.91(1 \mathrm{H}, \mathrm{d}, J=9.7 \mathrm{~Hz}), 8.18(1 \mathrm{H}, \mathrm{s})$. IR $(\mathrm{KBr}) \mathrm{cm}^{-1}: 3290,1940,1630$, 1590, 1500. Anal. Calcd for $\mathrm{C}_{26} \mathrm{H}_{30} \mathrm{~N}_{6} \mathrm{O}: \mathrm{C}, 70.56 ; \mathrm{H}, 6.83 ; \mathrm{N}, 18.99$. Found: C, $70.43 ; \mathrm{H}, 6.83 ; \mathrm{N}, 19.04$.

The following compounds, $\mathbf{5 b}$ and $\mathbf{5 f}$, were prepared with a similar procedure described for the preparation of $\mathbf{5 a}$.

6-[[3-[4-(Diphenylmethyl)-1-piperazinyl]propyl]amino][1,2,4]triazolo[1,5-b]pyridazine (5b) From $\mathbf{1 0 b}$ and $\mathbf{1 1 b}$ was prepared $\mathbf{5 b}(36 \%$ yield) as crystals, mp $139-140^{\circ} \mathrm{C}$ (from diethyl ether). ${ }^{1} \mathrm{H}-\mathrm{NMR}\left(\mathrm{CDCl}_{3}\right) \delta: 1.75-$ $1.90(4 \mathrm{H}, \mathrm{m}), 2.30-2.80(8 \mathrm{H}, \mathrm{m}), 3.45-3.55(2 \mathrm{H}, \mathrm{m}), 4.30(1 \mathrm{H}, \mathrm{s}), 6.55$ $(1 \mathrm{H}, \mathrm{d}, J=9.6 \mathrm{~Hz}), 7.16-7.46(10 \mathrm{H}, \mathrm{m}), 7.70(1 \mathrm{H}, \mathrm{d}, J=9.6 \mathrm{~Hz}), 8.16(1 \mathrm{H}$, s). IR (KBr) cm $\mathrm{cm}^{-1}$ 3290, 2810, 1590, 1500. Anal. Calcd for $\mathrm{C}_{25} \mathrm{H}_{29} \mathrm{~N}_{7} \cdot 0.5 \mathrm{H}_{2} \mathrm{O}: \mathrm{C}, 68.78 ; \mathrm{H}, 6.93 ; \mathrm{N}, 22.46$. Found: $\mathrm{C}, 68.72 ; \mathrm{H}, 6.86 ; \mathrm{N}$, 22.16.

6-[[2-[4-(Diphenylmethoxy)piperidino]ethyl]amino][1,2,4]triazolo[1,5b]pyridazine (5f) From 10a and 11a was prepared $\mathbf{5 f}$ (38\% yield) as crystals, mp $152-154^{\circ} \mathrm{C}$ (from ethanol-diethyl ether). ${ }^{1} \mathrm{H}-\mathrm{NMR}\left(\mathrm{CDCl}_{3}\right) \delta$ : $1.64-1.79(2 \mathrm{H}, \mathrm{m}), 1.84-1.98(2 \mathrm{H}, \mathrm{m}), 2.13-2.25(2 \mathrm{H}, \mathrm{m}), 2.59-2.65$ $(2 \mathrm{H}, \mathrm{m}), 2.72-2.82(2 \mathrm{H}, \mathrm{m}), 3.42-3.50(3 \mathrm{H}, \mathrm{m}), 5.39(1 \mathrm{H}, \mathrm{br} \mathrm{s}), 5.53(1 \mathrm{H}$, s), $6.76(1 \mathrm{H}, \mathrm{d}, J=9.5 \mathrm{~Hz}), 7.24-7.34(10 \mathrm{H}, \mathrm{m}), 7.75(1 \mathrm{H}, \mathrm{d}, J=9.5 \mathrm{~Hz})$, $8.17(1 \mathrm{H}, \mathrm{s})$. IR $(\mathrm{KBr}) \mathrm{cm}^{-1}: 3270,2940,1590,1500$. Anal. Calcd for $\mathrm{C}_{25} \mathrm{H}_{28} \mathrm{~N}_{6} \mathrm{O}$ : C, 70.07; H, 6.59; N, 19.61. Found: C, 69.66; H, 6.40; N, 20.03.

6-[3-[4-(Diphenylmethoxy)piperidino]propoxy][1,2,4]triazolo[1,5b]pyridazine Fumarate $(5 \mathrm{c})$ To a solution of $4 \mathrm{a}(0.390 \mathrm{~g}, 1.20 \mathrm{mmol})$ in tetrahydrofuran $(10 \mathrm{ml})$ was added sodium tert-butoxide $(0.127 \mathrm{~g}$, $1.32 \mathrm{mmol}$ ), and the mixture was refluxed for $30 \mathrm{~min}$. After cooling, 1a $(0.215 \mathrm{~g}, 1.39 \mathrm{mmol})$ was added, and the mixture was refluxed for $3 \mathrm{~h}$. After cooling, the reaction mixture was diluted with ice-cold water and extracted with ethyl acetate. The combined organic layer was washed with brine, dried, and concentrated. The residue was purified by column chromatography on silica gel eluted with ethyl acetate-methanol-triethylamine $(95: 5: 1)$, and the desired fractions were concentrated to give $0.383 \mathrm{~g}$ of the free base of $\mathbf{5 c}(71 \%$ yield). The free base $(0.357 \mathrm{~g}, 0.800 \mathrm{mmol})$ was dissolved in ethanol, followed by addition of fumaric acid $(0.093 \mathrm{~g}$, $0.800 \mathrm{mmol}$ ). The resulting crystals were recrystallized from ethanol to give $0.218 \mathrm{~g}$ of $\mathbf{5 c}, \mathrm{mp} 157-159^{\circ} \mathrm{C} .{ }^{1} \mathrm{H}-\mathrm{NMR}$ (DMSO- $\left.d_{6}\right) \delta: 1.55-1.76(2 \mathrm{H}$, $\mathrm{m}), 1.80-2.10(4 \mathrm{H}, \mathrm{m}), 2.25-2.45(2 \mathrm{H}, \mathrm{m}), 2.58-2.70(2 \mathrm{H}, \mathrm{m}), 2.78-$ $2.95(2 \mathrm{H}, \mathrm{m}), 3.35-3.50(1 \mathrm{H}, \mathrm{m}), 4.32-4.42(2 \mathrm{H}, \mathrm{m}), 5.64(1 \mathrm{H}, \mathrm{s}), 6.57$ $(2 \mathrm{H}, \mathrm{s}), 7.22-7.40(11 \mathrm{H}, \mathrm{m}), 8.31(1 \mathrm{H}, \mathrm{d}, J=9.8 \mathrm{~Hz}), 8.48(1 \mathrm{H}, \mathrm{s})$. IR (KBr) $\mathrm{cm}^{-1}: 3430,2920,2510,1720,1600,1550,1500$. Anal. Calcd for $\mathrm{C}_{30} \mathrm{H}_{33} \mathrm{~N}_{5} \mathrm{O}_{6}: \mathrm{C}, 64.39 ; \mathrm{H}, 5.94 ; \mathrm{N}, 12.51$. Found: $\mathrm{C}, 64.16 ; \mathrm{H}, 5.71 ; \mathrm{N}$, 12.32 .
The following compounds, $\mathbf{5 d}, \mathbf{5 h}, \mathbf{5 i}, \mathbf{5} \mathbf{k}$ and $\mathbf{5 m}$, were prepared with a similar procedure described for the preparation of $\mathbf{5 c}$.

6-[3-[4-(Diphenylmethoxy)piperidino]propoxy]-7-isopropyl[1,2,4]triazolo[1,5-b]pyridazine Fumarate (5d) From 4a and $\mathbf{1 b}$ was prepared the free base of $\mathbf{5 d}$ ( $56 \%$ yield). With fumaric acid, $\mathbf{5 d}$ was obtained as crystals, $\mathrm{mp} 163-165^{\circ} \mathrm{C}$ (from ethyl acetate). ${ }^{1} \mathrm{H}-\mathrm{NMR}$ (DMSO- $\left.d_{6}\right) \delta: 1.25(6 \mathrm{H}, \mathrm{d}$, $J=7.0 \mathrm{~Hz}), 1.52-1.72(2 \mathrm{H}, \mathrm{m}), 1.80-2.10(4 \mathrm{H}, \mathrm{m}), 2.20-2.36(2 \mathrm{H}, \mathrm{m})$, $2.53-2.63(2 \mathrm{H}, \mathrm{m}), 2.75-2.88(2 \mathrm{H}, \mathrm{m}), 3.07-3.21(1 \mathrm{H}, \mathrm{m}), 3.34-3.50$ $(1 \mathrm{H}, \mathrm{m}), 4.40(2 \mathrm{H}, \mathrm{t}, J=6.0 \mathrm{~Hz}), 5.63(1 \mathrm{H}, \mathrm{s}), 6.58(2 \mathrm{H}, \mathrm{s}), 7.18-7.40$ $(10 \mathrm{H}, \mathrm{m}), 8.09(1 \mathrm{H}, \mathrm{s}), 8.40(1 \mathrm{H}, \mathrm{s})$. IR $(\mathrm{KBr}) \mathrm{cm}^{-1}: 3030,2940,2870$, 2500, 1710, 1650, 1600, 1500. Anal. Calcd for $\mathrm{C}_{33} \mathrm{H}_{39} \mathrm{~N}_{5} \mathrm{O}_{6}: \mathrm{C}, 65.87 ; \mathrm{H}$, 6.53 ; N, 11.64. Found: C, 65.77; H, 6.46; N, 11.71 .

6-[2-[4-(Diphenylmethoxy)piperidino]ethoxy][1,2,4]triazolo[1,5b]pyridazine Fumarate (5h) From $4 \mathrm{~b}$ and $1 \mathrm{a}$ was prepared the free base of $\mathbf{5 h}(75 \%$ yield). With fumaric acid, $\mathbf{5 h}$ was obtained as crystals, $\mathrm{mp}$ $176-177^{\circ} \mathrm{C}$ (from ethanol). ${ }^{1} \mathrm{H}-\mathrm{NMR}$ (DMSO- $\left.d_{6}\right) \delta: 1.48-1.65(2 \mathrm{H}, \mathrm{m})$, $1.80-1.95(2 \mathrm{H}, \mathrm{m}), 2.20-2.38(2 \mathrm{H}, \mathrm{m}), 2.76-2.92(1 \mathrm{H}, \mathrm{m}), 2.82(2 \mathrm{H}, \mathrm{t}$, $J=5.5 \mathrm{~Hz}), 3.30-3.48(2 \mathrm{H}, \mathrm{m}), 4.46(2 \mathrm{H}, \mathrm{t}, J=5.5 \mathrm{~Hz}), 5.63(1 \mathrm{H}, \mathrm{s}), 6.62$ $(2 \mathrm{H}, \mathrm{s}), 7.22-7.39(11 \mathrm{H}, \mathrm{m}), 8.23(1 \mathrm{H}, \mathrm{d}, J=9.6 \mathrm{~Hz}), 8.47(1 \mathrm{H}, \mathrm{s})$. IR (KBr) $\mathrm{cm}^{-1}: 3130,2470,1700,1660,1600,1450$. Anal. Calcd for $\mathrm{C}_{29} \mathrm{H}_{31} \mathrm{~N}_{5} \mathrm{O}_{6}: \mathrm{C}, 61.80 ; \mathrm{H}, 5.90 ; \mathrm{N}, 12.43$. Found: C, 61.72; H, 5.65; N, 12.03 .

6-[4-[4-(Diphenylmethoxy)piperidino]butoxy][1,2,4] triazolo[1,5b]pyridazine Fumarate (5i) From $4 \mathbf{c}$ and $1 \mathbf{a}$ was prepared the free base of $\mathbf{5 i}$ (9.4\% yield). With fumaric acid, $\mathbf{5 i}$ was obtained as crystals, mp 159$161{ }^{\circ} \mathrm{C}$ (from methanol). ${ }^{1} \mathrm{H}-\mathrm{NMR}$ (DMSO- $\left.d_{6}\right) \delta: 1.52-1.98(6 \mathrm{H}, \mathrm{m})$, $2.26-2.40(2 \mathrm{H}, \mathrm{m}), 2.27-2.92(3 \mathrm{H}, \mathrm{m}),, 3.35-3.55(4 \mathrm{H}, \mathrm{m}), 4.36(2 \mathrm{H}, \mathrm{t}$, $J=6.1 \mathrm{~Hz}), 5.63(1 \mathrm{H}, \mathrm{s}), 6.57(2 \mathrm{H}, \mathrm{s}), 7.18-7.40(11 \mathrm{H}, \mathrm{m}), 8.29(1 \mathrm{H}, \mathrm{d}$, $J=9.6 \mathrm{~Hz}), 8.46(1 \mathrm{H}, \mathrm{s})$. IR $(\mathrm{KBr}) \mathrm{cm}^{-1}: 3080,2960,2510,1720$. Anal. Calcd for $\mathrm{C}_{31} \mathrm{H}_{35} \mathrm{~N}_{5} \mathrm{O}_{6}: \mathrm{C}, 64.91 ; \mathrm{H}, 6.15 ; \mathrm{N}, 12.21$. Found: $\mathrm{C}, 64.72 ; \mathrm{H}$, $6.10 ; \mathrm{N}, 12.06$.

6-[3-[4-(Diphenylmethoxy)piperidino]propoxy]-2-methyl[1,2,4]triazolo[1,5-b]pyridazine (5k) From $4 \mathbf{a}$ and $\mathbf{1 c}$ was prepared $5 \mathbf{k}(67 \%$ yield $)$ as crystals, mp $134-136{ }^{\circ} \mathrm{C}$ (from ethyl acetate-diethyl ether). ${ }^{1} \mathrm{H}-\mathrm{NMR}$ $\left(\mathrm{CDCl}_{3}\right) \delta: 1.70-2.24(8 \mathrm{H}, \mathrm{m}), 2.49(2 \mathrm{H}, \mathrm{t}, J=7.3 \mathrm{~Hz}), 2.59(3 \mathrm{H}, \mathrm{s}), 2.71-$ $2.82(2 \mathrm{H}, \mathrm{m}), 3.39-3.51(1 \mathrm{H}, \mathrm{m}), 4.43(2 \mathrm{H}, \mathrm{t}, J=6.4 \mathrm{~Hz}), 5.52(1 \mathrm{H}, \mathrm{s}), 6.95$ $(1 \mathrm{H}, \mathrm{d}, J=9.4 \mathrm{~Hz}), 7.25-7.36(10 \mathrm{H}, \mathrm{m}), 7.83(1 \mathrm{H}, \mathrm{d}, J=9.4 \mathrm{~Hz})$. IR $(\mathrm{KBr})$ $\mathrm{cm}^{-1}: 2940,1550,1490,1450$. Anal. Calcd for $\mathrm{C}_{27} \mathrm{H}_{31} \mathrm{~N}_{5} \mathrm{O}_{2}: \mathrm{C}, 70.87 ; \mathrm{H}$, 6.83; N, 15.31. Found: C, 70.67; H, 6.94; N, 15.34 .

2-tert-Butyl-6-[3-[4-(diphenylmethoxy)piperidino]propoxy][1,2,4]triazolo[1,5-b]pyridazine Fumarate $(5 \mathrm{~m})$ From $4 \mathrm{a}$ and $1 \mathrm{~d}$ was prepared the free base of $\mathbf{5 m}$ (33\% yield). With fumaric acid, $\mathbf{5 m}$ was obtained as crystals, mp $170-172{ }^{\circ} \mathrm{C}$ (from ethyl acetate). ${ }^{1} \mathrm{H}-\mathrm{NMR}$ (DMSO- $d_{6}$ ) $\delta: 1.38$ $(9 \mathrm{H}, \mathrm{s}), 1.52-1.72(2 \mathrm{H}, \mathrm{m}), 1.84-2.06(4 \mathrm{H}, \mathrm{m}), 2.22-2.36(2 \mathrm{H}, \mathrm{m})$, $2.52-2.62(2 \mathrm{H}, \mathrm{m}), 2.76-2.90(2 \mathrm{H}, \mathrm{m}), 3.34-3.48(1 \mathrm{H}, \mathrm{m}), 4.35(2 \mathrm{H}, \mathrm{t}$, $J=6.2 \mathrm{~Hz}), 5.64(1 \mathrm{H}, \mathrm{s}), 6.58(2 \mathrm{H}, \mathrm{s}), 7.20-7.39(11 \mathrm{H}, \mathrm{m}), 8.19(1 \mathrm{H}, \mathrm{d}$, $J=10.0 \mathrm{~Hz})$. IR $(\mathrm{KBr}) \mathrm{cm}^{-1}: 3400,2960,2490,1680,1550,1490$. Anal. Calcd for $\mathrm{C}_{34} \mathrm{H}_{41} \mathrm{~N}_{5} \mathrm{O}_{6}$ : C, 66.32; H, 6.71; N, 11.37. Found: C, 66.15; H, $6.74 ; \mathrm{N}, 11.28$.

6-[[3-[4-(Diphenylmethoxy)piperidino]propyl]thio][1,2,4]triazolo[1,5b]pyridazine Fumarate (5e) To a solution of 10c $(0.546 \mathrm{~g}, 2.00 \mathrm{mmol})$ and 11a $(0.535 \mathrm{~g}, 2.00 \mathrm{mmol})$ in acetonitrile $(15 \mathrm{ml})$ were added sodium iodide $(0.373 \mathrm{~g}, 2.50 \mathrm{mmol})$ and potassium carbonate $(0.277 \mathrm{~g}, 2.00 \mathrm{mmol})$, and the mixture was stirred at $50-60^{\circ} \mathrm{C}$ for $15 \mathrm{~h}$. After cooling, the reaction mixture was diluted with ice-cold water and extracted with ethyl acetate. The combined organic layer was washed with brine, dried and concentrated. The residue was purified by column chromatography on silica gel eluted with ethyl acetate-methanol-triethylamine $(95: 5: 1)$, and the desired fractions were concentrated to give $0.630 \mathrm{~g}$ of the free base of $5 \mathbf{e}(68 \%$ yield). The free base of 5e was dissolved in ethanol, followed by addition of fumaric acid $(0.159 \mathrm{~g}, 1.37 \mathrm{mmol})$. The resulting crystals were collected, washed with ethanol, and dried to give $0.435 \mathrm{~g}$ of $\mathbf{5 e}, \mathrm{mp} 185-187^{\circ} \mathrm{C} .{ }^{1} \mathrm{H}-$ NMR (DMSO- $\left.d_{6}\right) \delta: 1.52-1.74(2 \mathrm{H}, \mathrm{m}), 1.80-2.04(4 \mathrm{H}, \mathrm{m}), 2.24-2.40$ $(2 \mathrm{H}, \mathrm{m}), 2.51-2.62(2 \mathrm{H}, \mathrm{m}), 2.76-2.92(2 \mathrm{H}, \mathrm{m}), 3.22-3.30(2 \mathrm{H}, \mathrm{m})$, $3.32-3.48(1 \mathrm{H}, \mathrm{m}), 5.63(1 \mathrm{H}, \mathrm{s}), 6.59(2 \mathrm{H}, \mathrm{s}), 7.18-7.39(10 \mathrm{H}, \mathrm{m}), 7.56$ $(1 \mathrm{H}, \mathrm{d}, J=9.4 \mathrm{~Hz}), 8.25(1 \mathrm{H}, \mathrm{d}, J=9.4 \mathrm{~Hz}), 8.53(1 \mathrm{H}, \mathrm{s}) . \mathrm{IR}(\mathrm{KBr}) \mathrm{cm}^{-1}$ : $3070,2500,1720,1660,1600,1540,1460$. Anal. Calcd for $\mathrm{C}_{30} \mathrm{H}_{33} \mathrm{~N}_{5} \mathrm{O}_{5} \mathrm{~S}$. $0.5 \mathrm{H}_{2} \mathrm{O}: \mathrm{C}, 61.63 ; \mathrm{H}, 5.86 ; \mathrm{N}, 11.98$. Found: $\mathrm{C}, 61.98 ; \mathrm{H}, 5.83 ; \mathrm{N}, 11.95$.

Methyl 2-[6-[[3-[4-(Diphenylmethoxy)piperidino]propyl]thio]imidazo[1,2-b]pyridazin-2-yl]-2-methylpropionate Dihydrochloride (6d) With a similar procedure described for the preparation of $\mathbf{5 e}$, the free base of 6d from 10d and 11a (73\% yield) was prepared. With $4 \mathrm{~N}$ hydrogen chloride in ethyl acetate, 6d was obtained as a colorless amorphous (from diethyl ether). ${ }^{1} \mathrm{H}-\mathrm{NMR}$ (DMSO- $\left.d_{6}\right) \delta: 1.61(6 \mathrm{H}, \mathrm{s}), 1.80-2.30(6 \mathrm{H}, \mathrm{m}), 2.80-$ 
$3.74(9 \mathrm{H}, \mathrm{m}), 3.62(3 \mathrm{H}, \mathrm{s}), 5.64,5.69$ (each $0.5 \mathrm{H}, \mathrm{s}), 7.20-7.42(11 \mathrm{H}, \mathrm{m})$, $8.06(1 \mathrm{H}, \mathrm{d}, J=9.0 \mathrm{~Hz}), 8.37(1 \mathrm{H}, \mathrm{s}), 10.88(1 \mathrm{H}, \mathrm{br} \mathrm{s}) . \mathrm{IR}(\mathrm{KBr}) \mathrm{cm}^{-1}: 3300$, 2930, 2650, 1740. Anal. Calcd for $\mathrm{C}_{32} \mathrm{H}_{40} \mathrm{~N}_{4} \mathrm{O}_{3} \mathrm{SCl}_{2} \cdot \mathrm{H}_{2} \mathrm{O}: \mathrm{C}, 59.16 ; \mathrm{H}, 6.52$; $\mathrm{N}, 8.62$. Found: C, 58.92; H, 6.76; N, 8.86.

6-[[4-[4-(Diphenylmethoxy)piperidino]butyl]amino][1,2,4]triazolo[1,5-b]pyridazine $\mathbf{( 5 \mathrm { g } )}$ To a solution of $\mathbf{3 f}(1.83 \mathrm{~g}, 5.41 \mathrm{mmol})$ and $\mathbf{1 a}$ $(0.557 \mathrm{~g}, 3.60 \mathrm{mmol})$ in 1-butanol $(30 \mathrm{ml})$ was added $N$-ethyldiisopropylamine $(0.931 \mathrm{~g}, 7.20 \mathrm{mmol})$, and the mixture was refluxed for $14 \mathrm{~h}$. After cooling and evaporation of the solvent, the reaction mixture was diluted with ice-cold water and extracted with ethyl acetate. The combined organic layer was washed with brine, dried, and concentrated. The residue was purified by column chromatography on silica gel eluted with ethyl acetate-methanoltriethylamine $(45: 5: 1)$, and the desired fractions were concentrated. The resulting crystals were collected, washed with diethyl ether, and dried to give $0.149 \mathrm{~g}$ of $5 \mathrm{~g}$ (36\% yield), mp $102-104{ }^{\circ} \mathrm{C}$. ${ }^{1} \mathrm{H}-\mathrm{NMR}\left(\mathrm{CDCl}_{3}\right) \delta: 1.63-$ $2.06(8 \mathrm{H}, \mathrm{m}), 2.14-2.31(2 \mathrm{H}, \mathrm{m}), 2.41(2 \mathrm{H}, \mathrm{t}, J=6.6 \mathrm{~Hz}), 2.74-2.88(2 \mathrm{H}$, $\mathrm{m}), 3.48-3.36(2 \mathrm{H}, \mathrm{m}), 3.40-3.60(1 \mathrm{H}, \mathrm{m}), 5.52(1 \mathrm{H}, \mathrm{s}), 6.07(1 \mathrm{H}, \mathrm{brs})$, $6.71(1 \mathrm{H}, \mathrm{d}, J=9.6 \mathrm{~Hz}), 7.23-7.34(10 \mathrm{H}, \mathrm{m}), 7.71(1 \mathrm{H}, \mathrm{d}, J=9.6 \mathrm{~Hz}), 8.16$ $(1 \mathrm{H}, \mathrm{s})$. IR $(\mathrm{KBr}) \mathrm{cm}^{-1}: 3290,2940,1630,1590,1500,1450$. Anal. Calcd for $\mathrm{C}_{27} \mathrm{H}_{32} \mathrm{~N}_{6} \mathrm{O}: \mathrm{C}, 71.03 ; \mathrm{H}, 7.06 ; \mathrm{N}, 18.41$. Found: $\mathrm{C}, 70.78 ; \mathrm{H}, 6.77 ; \mathrm{N}$, 18.40 .

The following compounds, $\mathbf{5} \mathbf{j}, \mathbf{5} \mathbf{l}$ and $\mathbf{5 n}$, were prepared with a similar procedure described for the preparation of $\mathbf{5 g}$.

6-[[3-[4-(Diphenylmethoxy)piperidino]propyl] amino]-2-methyl[1,2,4]triazolo[1,5-b]pyridazine $(\mathbf{5 j})$ From $\mathbf{3 a}$ and $\mathbf{1 c}$ was prepared $\mathbf{5 j}(59 \%$ yield) as crystals, $\mathrm{mp} 119-120^{\circ} \mathrm{C}$ (from ethyl acetate-hexane). ${ }^{1} \mathrm{H}-\mathrm{NMR}$ $\left(\mathrm{CDCl}_{3}\right) \delta: 1.55-2.22(8 \mathrm{H}, \mathrm{m}), 2.51-2.56(2 \mathrm{H}, \mathrm{m}), 2.54(3 \mathrm{H}, \mathrm{s}), 2.80-$ $2.92(2 \mathrm{H}, \mathrm{m}), 3.42-3.52(3 \mathrm{H}, \mathrm{m}), 5.54(1 \mathrm{H}, \mathrm{s}), 6.59(1 \mathrm{H}, \mathrm{d}, J=9.6 \mathrm{~Hz})$, $6.99(1 \mathrm{H}, \mathrm{brs}), 7.26-7.36(10 \mathrm{H}, \mathrm{m}), 7.60(1 \mathrm{H}, \mathrm{d}, J=9.6 \mathrm{~Hz})$. IR $(\mathrm{KBr})$ $\mathrm{cm}^{-1}: 3290,2940,1630,1590,1490,1450$. Anal. Calcd for $\mathrm{C}_{27} \mathrm{H}_{32} \mathrm{~N}_{6} \mathrm{O}: \mathrm{C}$, 71.03; H, 7.06; N, 18.41. Found: C, 70.91; H, 6.95; N, 18.18 .

2-tert-Butyl-6-[[3-[4-(diphenylmethoxy)piperidino]propyl] amino]$[1,2,4]$ triazolo[1,5-b]pyridazine Fumarate (5l) From 3a and 1d was prepared the free base of $\mathbf{5 l}$ ( $43 \%$ yield). With fumaric acid, $\mathbf{5 1}$ was obtained as an amorphous. ${ }^{1} \mathrm{H}-\mathrm{NMR}\left(\mathrm{CDCl}_{3}\right) \delta: 1.45(9 \mathrm{H}, \mathrm{s}), 1.92-2.25(6 \mathrm{H}, \mathrm{m})$, $3.00-3.40(6 \mathrm{H}, \mathrm{m}), 3.50-3.58(2 \mathrm{H}, \mathrm{m}), 3.74-3.84(1 \mathrm{H}, \mathrm{m}), 5.43(1 \mathrm{H}, \mathrm{s})$, $6.81(2 \mathrm{H}, \mathrm{s}), 6.90(1 \mathrm{H}, \mathrm{d}, J=9.4 \mathrm{~Hz}), 7.25-7.32(10 \mathrm{H}, \mathrm{m}), 7.71(1 \mathrm{H}, \mathrm{d}$, $J=9.4 \mathrm{~Hz})$. IR (KBr) cm $\mathrm{cm}^{-1}: 3260,2960,1680,1580,1500$. Anal. Calcd for $\mathrm{C}_{34} \mathrm{H}_{42} \mathrm{~N}_{6} \mathrm{O}_{5} \cdot \mathrm{H}_{2} \mathrm{O} \cdot 0.5 \mathrm{Et}_{2} \mathrm{O}: \mathrm{C}, 64.55 ; \mathrm{H}, 7.37 ; \mathrm{N}, 12.55$. Found: $\mathrm{C}, 64.79 ; \mathrm{H}$, 7.76; N, 12.44.

Methyl 6-[[3-[4-(Diphenylmethoxy)piperidino]propyl]amino][1,2,4]triazolo[1,5-b]pyridazine-2-carboxylate (5n) From 3a and 1e (in $N, N$-dimethylformamide, at $\left.80^{\circ} \mathrm{C}\right)$ was prepared $\mathbf{5 n}(75 \%$ yield) as crystals, $\mathrm{mp}$ $93-96{ }^{\circ} \mathrm{C}$ (from ethanol-ethyl acetate). ${ }^{1} \mathrm{H}-\mathrm{NMR}\left(\mathrm{CDCl}_{3}\right) \delta: 1.64-1.86$ $(4 \mathrm{H}, \mathrm{m}), 1.92-2.06(2 \mathrm{H}, \mathrm{m}), 2.08-2.26(2 \mathrm{H}, \mathrm{m}), 2.56(2 \mathrm{H}, \mathrm{t}, J=5.5 \mathrm{~Hz})$, $2.82-2.94(2 \mathrm{H}, \mathrm{m}), 3.42-3.56(3 \mathrm{H}, \mathrm{m}), 4.03(3 \mathrm{H}, \mathrm{s}), 5.54(1 \mathrm{H}, \mathrm{s}), 6.71$ $(1 \mathrm{H}, \mathrm{d}, J=9.6 \mathrm{~Hz}), 7.22-7.38(10 \mathrm{H}, \mathrm{m}), 7.64(1 \mathrm{H}, \mathrm{brs}), 7.72(1 \mathrm{H}, \mathrm{d}$, $J=9.6 \mathrm{~Hz})$. IR $(\mathrm{KBr}) \mathrm{cm}^{-1}: 2950,1740$. Anal. Calcd for $\mathrm{C}_{28} \mathrm{H}_{32} \mathrm{~N}_{6} \mathrm{O}_{3}$. $0.5 \mathrm{H}_{2} \mathrm{O}: \mathrm{C}, 65.99 ; \mathrm{H}, 6.53 ; \mathrm{N}, 16.49$. Found: C, $65.69 ; \mathrm{H}, 6.28 ; \mathrm{N}, 16.58$.

Ethyl 2-[6-[[3-[4-(Diphenylmethoxy)piperidino]propyl]amino]imidazo[1,2-b]pyridazin-2-yl]-2-methylpropionate Difumarate (6a) A solution of 3a $(6.49 \mathrm{~g}, 20.0 \mathrm{mmol})$ and $\mathbf{2 d}(2.68 \mathrm{~g}, 10.0 \mathrm{mmol})$ in $\mathrm{N}$-methyl-2pyrrolidinone $(13.4 \mathrm{ml})$ was stirred at $191-195^{\circ} \mathrm{C}$ under nitrogen gas for $4.5 \mathrm{~h}$. After cooling, the reaction mixture was diluted with aqueous solution of sodium hydrogen carbonate and extracted with ethyl acetate. The combined organic layer was washed with water and concentrated. The residue was purified by column chromatography on silica gel eluted with ethyl acetate-methanol-triethylamine $(100: 5: 1)$, and the desired fractions were concentrated to give the free base of $5.14 \mathrm{~g}$ of $6 \mathrm{a}$ ( $65 \%$ yield). The free base of $6 \mathrm{a}(5.14 \mathrm{~g}, 9.22 \mathrm{mmol})$ and fumaric acid $(2.15 \mathrm{~g}, 18.5 \mathrm{mmol})$ was dissolved in ethanol, and the solvent was evaporated. The residue was crystallized from acetone, followed by drying to give $5.69 \mathrm{~g}$ of $\mathbf{6 a}, \mathrm{mp} 126-$ $128^{\circ} \mathrm{C} .{ }^{1} \mathrm{H}-\mathrm{NMR}$ (DMSO- $\left.d_{6}\right) \delta: 1.12(3 \mathrm{H}, \mathrm{t}, J=7.1 \mathrm{~Hz}), 1.51(6 \mathrm{H}, \mathrm{s})$, $1.65-2.04(6 \mathrm{H}, \mathrm{m}), 2.54-2.82(4 \mathrm{H}, \mathrm{m}), 2.94-3.08(2 \mathrm{H}, \mathrm{m}), 3.16-3.28$ $(2 \mathrm{H}, \mathrm{m}), 3.44-3.58(1 \mathrm{H}, \mathrm{m}), 4.03(2 \mathrm{H}, \mathrm{q}, J=7.1 \mathrm{~Hz}), 5.64(1 \mathrm{H}, \mathrm{s}), 6.60$ $(4 \mathrm{H}, \mathrm{s}), 6.58(1 \mathrm{H}, \mathrm{d}, J=9.7 \mathrm{~Hz}), 6.98(1 \mathrm{H}, \mathrm{br} \mathrm{s}), 7.19-7.42(10 \mathrm{H}, \mathrm{m}), 7.59$ $(1 \mathrm{H}, \mathrm{d}, J=9.7 \mathrm{~Hz}), 7.62(1 \mathrm{H}, \mathrm{s})$. IR $(\mathrm{KBr}) \mathrm{cm}^{-1}: 3240,2960,2880,2650$, 1730, 1570, 1490. Anal. Calcd for $\mathrm{C}_{41} \mathrm{H}_{49} \mathrm{~N}_{5} \mathrm{O}_{11}: \mathrm{C}, 62.50 ; \mathrm{H}, 6.27 ; \mathrm{N}, 8.89$. Found: C, 62.28; H, 6.15; N, 8.97.

The following compounds, $\mathbf{6 e}, \mathbf{6 i}$ and $\mathbf{6 j}$, were prepared with a similar procedure described for the preparation of $\mathbf{6 a}$.

Ethyl 2-[6-[N-[3-[4-(Diphenylmethoxy)piperidino]propyl]methylamino]imidazo[1,2-b]pyridazin-2-yl]-2-methylpropionate Dihydrochloride (6e) From $3 \mathbf{e}$ and $2 \mathbf{d}$ was prepared the free base of $\mathbf{6 e}$ (53\% yield) as an amorphous. With $4 \mathrm{~N}$ hydrogen chloride in ethyl acetate, $6 \mathbf{e}$ was obtained as an amorphous (from diethyl ether). ${ }^{1} \mathrm{H}-\mathrm{NMR}$ (DMSO- $\left.d_{6}\right) \delta: 1.16(3 \mathrm{H}, \mathrm{t}$, $J=7.0 \mathrm{~Hz}), 1.63(6 \mathrm{H}, \mathrm{s}), 1.85-2.25(6 \mathrm{H}, \mathrm{m}), 2.80-3.10(4 \mathrm{H}, \mathrm{m}), 3.30-$ $3.70(5 \mathrm{H}, \mathrm{m}), 3.09(1.5 \mathrm{H}, \mathrm{s}), 3.11(1.5 \mathrm{H}, \mathrm{s}), 4.11(2 \mathrm{H}, \mathrm{q}, J=7.0 \mathrm{~Hz}), 5.63$ $(0.5 \mathrm{H}, \mathrm{s}), 5.68(0.5 \mathrm{H}, \mathrm{s}), 7.20-7.40(10 \mathrm{H}, \mathrm{m}), 7.58-7.63(1 \mathrm{H}, \mathrm{m}), 8.03$ $(1 \mathrm{H}, \mathrm{d}, J=10.5 \mathrm{~Hz}), 8.25(1 \mathrm{H}, \mathrm{s}), 10.97(1 \mathrm{H}, \mathrm{brs}) . \mathrm{IR}(\mathrm{KBr}) \mathrm{cm}^{-1}: 3400$, 2930, 2640, 1730, 1600, 1510. Anal. Calcd for $\mathrm{C}_{34} \mathrm{H}_{45} \mathrm{~N}_{5} \mathrm{O}_{3} \mathrm{Cl}_{2} \cdot \mathrm{H}_{2} \mathrm{O}: \mathrm{C}$, $61.81 ; \mathrm{H}, 7.17 ; \mathrm{N}, 10.60$. Found: C, 61.92; H, 7.47; N, 10.29.

Ethyl 1-[6-[[3-[4-(Diphenylmethoxy)piperidino]propyl]amino]imidazo[1,2-b]pyridazin-2-yl]cyclopropane-1-carboxylate Dihydrochloride (6i) From 3a and 2a was prepared the free base of $6 \mathbf{i}$ (50\% yield) as an oil. With $4 \mathrm{~N}$ hydrogen chloride in ethyl acetate, $\mathbf{6 i}$ was obtained as crystals, $\mathrm{mp}$ $196-199^{\circ} \mathrm{C}$ (from ethyl acetate). ${ }^{1} \mathrm{H}-\mathrm{NMR}\left(\mathrm{CDCl}_{3}\right) \delta: 1.28(3 \mathrm{H}, \mathrm{t}$, $J=7.0 \mathrm{~Hz}), 1.72-2.46(10 \mathrm{H}, \mathrm{m}), 3.06-3.24(4 \mathrm{H}, \mathrm{m}), 3.40-3.56(4 \mathrm{H}, \mathrm{m})$, $3.84-3.90(1 \mathrm{H}, \mathrm{m}), 4.22(2 \mathrm{H}, \mathrm{q}, J=7.0 \mathrm{~Hz}), 5.44(1 \mathrm{H}, \mathrm{s}), 7.22-7.42(11 \mathrm{H}$, m), $7.85(1 \mathrm{H}, \mathrm{s}), 8.05(1 \mathrm{H}, \mathrm{br} \mathrm{s}), 8.07(1 \mathrm{H}, \mathrm{d}, J=10.0 \mathrm{~Hz}), 11.34(1 \mathrm{H}, \mathrm{br} \mathrm{s})$. IR (KBr) cm ${ }^{-1}: 3210,3060,2940,2650,1720,1610,1510$. Anal. Calcd for $\mathrm{C}_{33} \mathrm{H}_{41} \mathrm{~N}_{5} \mathrm{O}_{3} \mathrm{Cl}_{2} \cdot 0.5 \mathrm{H}_{2} \mathrm{O}: \mathrm{C}, 62.36 ; \mathrm{H}, 6.66 ; \mathrm{N}, 11.02$. Found: $\mathrm{C}, 62.48 ; \mathrm{H}$, 6.49; N, 11.18 .

Ethyl 1-[6-[[3-[4-(Diphenylmethoxy)piperidino]propyl]amino]imidazo[1,2-b]pyridazin-2-yl]cyclopentane-1-carboxylate Dihydrochloride (6j) From 3a and $\mathbf{2 b}$ was prepared the free base of $\mathbf{6 j}$ ( $43 \%$ yield) as an oil. With $4 \mathrm{~N}$ hydrogen chloride in ethyl acetate, $\mathbf{6 j}$ was obtained as an amorphous (from diethyl ether). ${ }^{1} \mathrm{H}-\mathrm{NMR}$ (DMSO- $\left.d_{6}\right) \delta: 1.15(3 \mathrm{H}, \mathrm{t}, J=7.1 \mathrm{~Hz}$ ), $1.60-2.50(10 \mathrm{H}, \mathrm{m}), 2.80-3.76(13 \mathrm{H}, \mathrm{m}), 4.11(2 \mathrm{H}, \mathrm{q}, J=7.1 \mathrm{~Hz}), 5.65$ $(0.5 \mathrm{H}, \mathrm{s}), 5.70(0.5 \mathrm{H}, \mathrm{s}), 7.19-7.44(11 \mathrm{H}, \mathrm{m}), 7.94(0.5 \mathrm{H}, \mathrm{d}, J=9.4 \mathrm{~Hz})$, $7.95(0.5 \mathrm{H}, \mathrm{d}, J=10.0 \mathrm{~Hz}), 8.06(1 \mathrm{H}, \mathrm{br} \mathrm{s}), 8.28(0.5 \mathrm{H}, \mathrm{s}), 8.29(0.5 \mathrm{H}, \mathrm{s})$, 10.75 (1H, br s). IR (KBr) cm $\mathrm{cm}^{-1}: 3230,3060,2940,2640,1730,1610,1510$. Anal. Calcd for $\mathrm{C}_{35} \mathrm{H}_{45} \mathrm{~N}_{5} \mathrm{O}_{3} \mathrm{Cl}_{2} \cdot \mathrm{H}_{2} \mathrm{O}: \mathrm{C}, 62.49 ; \mathrm{H}, 7.04 ; \mathrm{N}, 10.41$. Found: C, $62.65 ; \mathrm{H}, 7.22 ; \mathrm{N}, 10.69$.

Ethyl 2-[6-[[3-[4-(Diphenylmethyl)-1-piperazinyl]propyl]amino]imidazo[1,2-b]pyridazin-2-yl]-2-methylpropionate Trihydrochloride (6f) A mixture of $\mathbf{3 b}(1.31 \mathrm{~g}, 4.23 \mathrm{mmol})$ and $2 \mathbf{d}(0.567 \mathrm{~g}, 2.12 \mathrm{mmol})$ was stirred at $185^{\circ} \mathrm{C}$ for $3 \mathrm{~h}$. After cooling, the reaction mixture was diluted with an aqueous solution of sodium hydrogen carbonate and extracted with ethyl acetate. The organic layer was washed with brine, dried, and concentrated. The residue was purified by column chromatography on silica gel eluted with ethyl acetate-methanol-triethylamine $(50: 5: 1)$, and the desired fractions were concentrated. The free base of 6 f $(1.07 \mathrm{mmol}, 50 \%$ yield $)$ was dissolved in ethanol, and addition of $4 \mathrm{~N}$ hydrogen chloride in ethyl acetate $(0.80 \mathrm{ml}, 3.21 \mathrm{mmol})$ to the solution was followed by concentration. The residue was crystallized from ethanol, washed with ethanol-ethyl acetate, and dried to give $0.502 \mathrm{~g}$ of $\mathbf{6 f}, \mathrm{mp} 190-193^{\circ} \mathrm{C} .{ }^{1} \mathrm{H}-\mathrm{NMR}$ (DMSO- $d_{6}$ ) $\delta$ : $1.18(3 \mathrm{H}, \mathrm{t}, J=7.1 \mathrm{~Hz}), 1.63(6 \mathrm{H}, \mathrm{s}), 2.00-2.18(2 \mathrm{H}, \mathrm{m}), 2.80-3.80(13 \mathrm{H}$, $\mathrm{m}), 4.13(2 \mathrm{H}, \mathrm{q}, J=7.1 \mathrm{~Hz}), 5.02(1 \mathrm{H}, \mathrm{br} \mathrm{s}), 7.24-7.41(8 \mathrm{H}, \mathrm{m}), 7.60-7.76$ $(5 \mathrm{H}, \mathrm{m}), 7.98(1 \mathrm{H}, \mathrm{d}, J=9.6 \mathrm{~Hz}), 8.09(1 \mathrm{H}, \mathrm{br} \mathrm{s}), 8.23(1 \mathrm{H}, \mathrm{s}) . \mathrm{IR}(\mathrm{KBr})$ $\mathrm{cm}^{-1}: 3460,3250,2980,2500,1730,1610,1510$. Anal. Calcd for $\mathrm{C}_{32} \mathrm{H}_{43} \mathrm{~N}_{6} \mathrm{O}_{2} \mathrm{Cl}_{3} \cdot \mathrm{H}_{2} \mathrm{O}: \mathrm{C}, 57.50 ; \mathrm{H}, 6.79 ; \mathrm{N}, 12.58$. Found: $\mathrm{C}, 57.27 ; \mathrm{H}, 6.52$; $\mathrm{N}, 12.55$.

The following compounds, $6 \mathrm{~g}, \mathbf{6 h}, \mathbf{6 k}, \mathbf{6} \mathbf{l}$ and $\mathbf{6 m}$, were prepared with a similar procedure described for the preparation of $\mathbf{6} \mathbf{f}$.

Ethyl 2-[6-[[3-[4-[Bis(4-fluorophenyl)methoxy]piperidino]propyl]amino]imidazo[1,2-b]pyridazin-2-yl]-2-methylpropionate Difumarate (6g) From $3 \mathbf{c}$ and $\mathbf{2 d}$ was prepared the free base of $\mathbf{6 g}$ (43\% yield) as an oil. With fumaric acid, $6 \mathrm{~g}$ was obtained as crystals, mp $159-161^{\circ} \mathrm{C}$ (from acetone). ${ }^{1} \mathrm{H}-\mathrm{NMR}$ (DMSO- $\left.d_{6}\right) \delta: 1.11(3 \mathrm{H}, \mathrm{t}, J=7.1 \mathrm{~Hz}), 1.50(6 \mathrm{H}, \mathrm{s})$, $1.56-2.00(6 \mathrm{H}, \mathrm{m}), 2.38-2.70(4 \mathrm{H}, \mathrm{m}), 2.82-3.00(2 \mathrm{H}, \mathrm{m}), 3.14-3.30$ $(2 \mathrm{H}, \mathrm{m}), 3.36-3.50(1 \mathrm{H}, \mathrm{m}), 4.02(2 \mathrm{H}, \mathrm{q}, J=7.1 \mathrm{~Hz}), 5.69(1 \mathrm{H}, \mathrm{s}), 6.59$ $(1 \mathrm{H}, \mathrm{d}, J=9.7 \mathrm{~Hz}), 6.60(4 \mathrm{H}, \mathrm{s}), 6.96(1 \mathrm{H}, \mathrm{br} \mathrm{s}), 7.12-7.21(4 \mathrm{H}, \mathrm{m}), 7.36-$ $7.43(4 \mathrm{H}, \mathrm{m}), 7.61(1 \mathrm{H}, \mathrm{d}, J=9.7 \mathrm{~Hz}), 7.65(1 \mathrm{H}, \mathrm{s}) . \mathrm{IR}(\mathrm{KBr}) \mathrm{cm}^{-1}: 3350$, 2920, 2500, 1870, 1740, 1590, 1580, 1500. Anal. Calcd for $\mathrm{C}_{41} \mathrm{H}_{47} \mathrm{~N}_{5} \mathrm{O}_{11} \mathrm{~F}_{2}$. $0.5 \mathrm{H}_{2} \mathrm{O}: \mathrm{C}, 59.13 ; \mathrm{H}, 5.81 ; \mathrm{N}, 8.41$. Found: C, 58.94; H, 5.84; N, 8.34.

Ethyl 2-[6-[[3-[4-(Hydroxydiphenylmethyl)piperidino]propyl]amino]imidazo[1,2-b]pyridazin-2-yl]-2-methylpropionate Dihydrochloride (6h) From 3d and $2 \mathbf{d}$ was prepared (at $\left.160^{\circ} \mathrm{C}\right)$ the free base of $\mathbf{6 h}(51 \%$ yield). With $4 \mathrm{~N}$ hydrogen chloride in ethyl acetate, $\mathbf{6 h}$ was obtained as an amorphous: ${ }^{1} \mathrm{H}-\mathrm{NMR}\left(\mathrm{CDCl}_{3}\right) \delta: 1.24(3 \mathrm{H}, \mathrm{t}, J=7.0 \mathrm{~Hz}), 1.76(6 \mathrm{H}, \mathrm{s}), 2.05-$ $3.90(15 \mathrm{H}, \mathrm{m}), 4.20(2 \mathrm{H}, \mathrm{q}, J=7.0 \mathrm{~Hz}), 7.05-8.35(13 \mathrm{H}, \mathrm{m}), 10.80(1 \mathrm{H}$, brs). IR (KBr) $\mathrm{cm}^{-1}: 3220,2900,1730,1610,1510$. Anal. Calcd for $\mathrm{C}_{33} \mathrm{H}_{43} \mathrm{~N}_{5} \mathrm{O}_{3} \mathrm{Cl}_{2} \cdot \mathrm{H}_{2} \mathrm{O} \cdot \mathrm{Et}_{2} \mathrm{O}: \mathrm{C}, 61.49 ; \mathrm{H}, 7.37 ; \mathrm{N}, 10.24$. Found: C, 61.47; H, $7.36 ; \mathrm{N}, 9.87$.

2-[6-[[3-[4-(Diphenylmethoxy)piperidino]propyl]amino]imidazo[1,2b]pyridazin-2-yl]-2-methylpropanol (6k) From 3a and 2e was prepared 6k (66\% yield) as crystals, mp $105-108^{\circ} \mathrm{C}$ (from diethyl ether). ${ }^{1} \mathrm{H}-\mathrm{NMR}$ 
$\left(\mathrm{CDCl}_{3}\right) \delta: 1.34(6 \mathrm{H}, \mathrm{s}), 1.64-2.20(10 \mathrm{H}, \mathrm{m}), 2.46-2.54(2 \mathrm{H}, \mathrm{m}), 2.80-$ $2.88(2 \mathrm{H}, \mathrm{m}), 3.34-3.56(3 \mathrm{H}, \mathrm{m}), 3.65(1 \mathrm{H}, \mathrm{s}), 5.54(1 \mathrm{H}, \mathrm{s}), 6.32(1 \mathrm{H}, \mathrm{d}$, $J=9.5 \mathrm{~Hz}), 7.20-7.40(10 \mathrm{H}, \mathrm{m}), 7.44(1 \mathrm{H}, \mathrm{s}), 7.48(1 \mathrm{H}, \mathrm{d}, J=9.5 \mathrm{~Hz}) . \mathrm{IR}$ $(\mathrm{KBr}) \mathrm{cm}^{-1}: 3260,2940,1630,1570,1490$. Anal. Calcd for $\mathrm{C}_{31} \mathrm{H}_{39} \mathrm{~N}_{5} \mathrm{O}_{2}$. $0.5 \mathrm{H}_{2} \mathrm{O}: \mathrm{C}, 71.24 ; \mathrm{H}, 7.71 ; \mathrm{N}, 13.40$. Found: C, 71.22; H, 7.87; N, 13.32 .

2-[6-[[3-[4-(Diphenylmethoxy)piperidino]propyl]amino]imidazo[1,2b]pyridazin-2-yl]-2-methylpropionamide Dihydrochloride (61) From 3a and $\mathbf{2 f}$ was prepared the free base of $\mathbf{6 1}$ (78\% yield). With $4 \mathrm{~N}$ hydrogen chloride in ethyl acetate, $\mathbf{6}$ was obtained as an amorphous. ${ }^{1} \mathrm{H}-\mathrm{NMR}$ (DMSO- $d_{6}$ ) $\delta: 1.58(6 \mathrm{H}, \mathrm{s}), 1.74-2.24(10 \mathrm{H}, \mathrm{m}), 2.84-3.76(5 \mathrm{H}, \mathrm{m}), 5.65(0.5 \mathrm{H}, \mathrm{s})$, $5.69(0.5 \mathrm{H}, \mathrm{s}), 7.19-7.42(11 \mathrm{H}, \mathrm{m}), 7.75-7.90(1 \mathrm{H}, \mathrm{m}), 7.95(1 \mathrm{H}, \mathrm{d}$, $J=9.8 \mathrm{~Hz}), 8.15(0.5 \mathrm{H}, \mathrm{s}), 8.18(0.5 \mathrm{H}, \mathrm{s}), 10.48(1 \mathrm{H}, \mathrm{br} \mathrm{s}), 10.83(1 \mathrm{H}, \mathrm{br} \mathrm{s})$. IR $(\mathrm{KBr}) \mathrm{cm}^{-1}: 3240,2940,2700,1570,1610,1500$. Anal. Calcd for $\mathrm{C}_{31} \mathrm{H}_{40} \mathrm{~N}_{6} \mathrm{O}_{2} \mathrm{Cl}_{2} \cdot \mathrm{AcOEt}: \mathrm{C}, 64.11 ; \mathrm{H}, 7.38 ; \mathrm{N}, 12.82$. Found: $\mathrm{C}, 63.70 ; \mathrm{H}$, $7.27 ; \mathrm{N}, 12.34$.

2-[6-[[3-[4-(Diphenylmethoxy)piperidino]propyl]amino]imidazo[1,2$b$ ]pyridazin-2-yl]- $N, N, 2$-trimethylpropionamide Dihydrochloride (6m) From 3a and $\mathbf{2 g}$ was prepared the free base of $\mathbf{6 m}$ (75\% yield) as an amorphous. With $4 \mathrm{~N}$ hydrogen chloride in ethyl acetate, $\mathbf{6 m}$ was obtained as crystals, mp $183^{\circ} \mathrm{C}$ (from acetone). ${ }^{1} \mathrm{H}-\mathrm{NMR}$ (DMSO- $\left.d_{6}\right) \delta$ : $1.56(6 \mathrm{H}, \mathrm{s})$, $1.84-2.22(8 \mathrm{H}, \mathrm{m}), 2.76(6 \mathrm{H}, \mathrm{s}), 2.80-3.74(7 \mathrm{H}, \mathrm{m}), 5.65(0.5 \mathrm{H}, \mathrm{s}), 5.69$ $(0.5 \mathrm{H}, \mathrm{s}), 7.22-7.42(11 \mathrm{H}, \mathrm{m}), 7.91(1 \mathrm{H}, \mathrm{d}, J=9.8 \mathrm{~Hz}), 8.15(1 \mathrm{H}, \mathrm{br} \mathrm{s}), 8.18$ $(1 \mathrm{H}, \mathrm{s}), 10.94(2 \mathrm{H}, \mathrm{brs})$. IR $(\mathrm{KBr}) \mathrm{cm}^{-1}: 3240,2930,2660,1630,1610$, 1500. Anal. Calcd for $\mathrm{C}_{33} \mathrm{H}_{44} \mathrm{~N}_{6} \mathrm{O}_{2} \mathrm{Cl}_{2} \cdot 1.5 \mathrm{H}_{2} \mathrm{O}: \mathrm{C}, 60.54 ; \mathrm{H}, 7.24 ; \mathrm{N}, 12.84$. Found: C, 60.48; H, 7.28; N, 12.90 .

2-[6-[3-[4-(Diphenylmethoxy)piperidino]propoxy]imidazo[1,2-b]pyridazin-2-yl]-2-methylpropionic Acid (6n) To a solution of 4a $(0.570 \mathrm{~g}$, $1.75 \mathrm{mmol})$ in $N, N$-dimethylformamide $(5 \mathrm{ml})$ was added $60 \%$ sodium hydride (dispersion in oil) $(0.070 \mathrm{~g}, 1.75 \mathrm{mmol})$, and the mixture was stirred at room temperature under reduced pressure for $30 \mathrm{~min}$. Addition of $\mathbf{2 h}$ $(0.520 \mathrm{~g}, 1.75 \mathrm{mmol})$ to the mixture was followed by stirring at room temperature for $8 \mathrm{~h}$. The reaction mixture was diluted with ice-cold water and extracted with ethyl acetate. The combined organic layer was washed with brine, dried, and concentrated. The residue was purified by column chromatography on silica gel eluted with ethyl acetate-methanol-triethylamine $(195: 5: 1)$, and the desired fractions were concentrated to give $0.596 \mathrm{~g}$ of tert-butyl 2-[6-[3-[4-(diphenylmethoxy)piperidino]propoxy]imidazo[1,2-b]pyridazin-2-yl]-2-methylpropionate $(58 \%$ yield). The tert-butyl ester $(0.818 \mathrm{~g}, 1.40 \mathrm{mmol})$ was dissolved in 1-butanol $(8 \mathrm{ml})$, and addition of potassium hydroxide $(0.393 \mathrm{~g}, 7.00 \mathrm{mmol})$ to the solution was followed by stirring at $90^{\circ} \mathrm{C}$ for $14 \mathrm{~h}$. After cooling, the reaction mixture was neutralized with $1 \mathrm{~N}$ hydrochloric acid and extracted with ethyl acetate. The combined organic layer was washed with brine, dried, and concentrated. The resulting crystals were washed with ethyl acetate and dried to give $0.465 \mathrm{~g}$ of $6 \mathbf{n}(62 \%$ yield), mp $183-185^{\circ} \mathrm{C} .{ }^{1} \mathrm{H}-\mathrm{NMR}\left(\mathrm{DMSO}-d_{6}\right) \delta: 1.52(6 \mathrm{H}, \mathrm{s}), 1.80-2.30$ $(6 \mathrm{H}, \mathrm{m}), 3.10-3.70(7 \mathrm{H}, \mathrm{m}), 4.30-4.40(2 \mathrm{H}, \mathrm{m}), 5.68(1 \mathrm{H}, \mathrm{s}), 6.82(1 \mathrm{H}, \mathrm{d}$, $J=9.6 \mathrm{~Hz}), 7.20-7.41(10 \mathrm{H}, \mathrm{m}), 7.93(1 \mathrm{H}, \mathrm{s}), 7.96(1 \mathrm{H}, \mathrm{d}, J=9.6 \mathrm{~Hz}) . \mathrm{IR}$ $(\mathrm{KBr}) \mathrm{cm}^{-1}: 3350,2940,2590,1720$. Anal. Calcd for $\mathrm{C}_{31} \mathrm{H}_{36} \mathrm{~N}_{4} \mathrm{O}_{4} \cdot 2.5 \mathrm{H}_{2} \mathrm{O}$ : C, 64.90; H, 7.20; N, 9.77. Found: C, 65.15; H, 6.73; N, 9.52.

Ethyl 2-[6-[3-[4-(Diphenylmethoxy)piperidino]propoxy]imidazo[1,2b]pyridazin-2-yl]-2-methylpropionate Difumarate (6b) Compound 6n $(0.529 \mathrm{~g}, 1.00 \mathrm{mmol})$ was dissolved in $N, N$-dimethylformamide $(3 \mathrm{ml})$, and addition of $N$-ethyldiisopropylamine $(0.207 \mathrm{ml}, 1.20 \mathrm{mmol})$ and iodoethane $(0.135 \mathrm{ml}, 1.30 \mathrm{mmol})$ was added to the solution was followed by stirring at room temperature for $15 \mathrm{~h}$. The reaction mixture was diluted with ice-cold water and extracted with ethyl acetate. The combined organic layer was washed with brine, dried, and concentrated. The residue was purified by column chromatography on silica gel eluted with ethyl acetate-methanol-triethylamine $(100: 5: 1)$, and the desired fractions were concentrated. The free base of $6 \mathbf{b}(0.665 \mathrm{mmol}, 66 \%$ yield $)$ was dissolved in ethyl acetate, and addition of a solution of fumaric acid $(0.153 \mathrm{~g}, 1.32 \mathrm{mmol})$ in methanol to the solution was followed by concentration. The resulting crystals were washed with ethyl acetate and dries to give $0.406 \mathrm{~g}$ of $\mathbf{6 b}, \mathrm{mp} 116-122{ }^{\circ} \mathrm{C} .{ }^{1} \mathrm{H}$ NMR (DMSO- $\left.d_{6}\right) \delta: 1.12(3 \mathrm{H}, \mathrm{t}, J=7.1 \mathrm{~Hz}), 1.50-1.80(2 \mathrm{H}, \mathrm{m}), 1.54(6 \mathrm{H}$, $\mathrm{s}), 1.82-2.16(4 \mathrm{H}, \mathrm{m}), 2.40-2.62(2 \mathrm{H}, \mathrm{m}), 2.64-2.78(2 \mathrm{H}, \mathrm{m}), 2.82-$ $3.00(2 \mathrm{H}, \mathrm{m}), 3.40-3.54(1 \mathrm{H}, \mathrm{m}), 4.04(2 \mathrm{H}, \mathrm{q}, J=7.1 \mathrm{~Hz}), 4.26-4.36(2 \mathrm{H}$, $\mathrm{m}), 5.64(1 \mathrm{H}, \mathrm{s}), 6.60(4 \mathrm{H}, \mathrm{s}), 6.80(1 \mathrm{H}, \mathrm{d}, J=9.8 \mathrm{~Hz}), 7.19-7.40(10 \mathrm{H}, \mathrm{m})$, $7.91(1 \mathrm{H}, \mathrm{s}), 7.92(1 \mathrm{H}, \mathrm{d}, J=9.8 \mathrm{~Hz}) . \mathrm{IR}(\mathrm{KBr}) \mathrm{cm}^{-1}: 2980,2580,1730$, 1680. Anal. Calcd for $\mathrm{C}_{41} \mathrm{H}_{48} \mathrm{~N}_{4} \mathrm{O}_{12}$ : C, 61.72; H, 6.19; N, 7.02. Found: C, $61.61 ; \mathrm{H}, 6.11 ; \mathrm{N}, 6.85$.

Ethyl 2-[6-[4-[4-(Diphenylmethoxy)piperidino]butyl]imidazo[1,2-b]pyridazin-2-yl]-2-methylpropionate Dihydrochloride (6c) To a solution of $10 \mathrm{e}(0.828 \mathrm{~g}, 2.56 \mathrm{mmol})$ in acetonitrile $(10 \mathrm{ml})$ was added $11 \mathrm{a}(0.752 \mathrm{~g}$, $2.81 \mathrm{mmol})$, potassium iodide $(0.552 \mathrm{~g}, 3.33 \mathrm{mmol})$ and potassium carbonate
$(0.460 \mathrm{~g}, 3.33 \mathrm{mmol})$, and the mixture was stirred at $60^{\circ} \mathrm{C}$ for $4 \mathrm{~h}$ and refluxed for $18 \mathrm{~h}$. After cooling, the reaction mixture was diluted with ice-cold water and extracted with ethyl acetate. The combined organic layer was washed with brine, dried, and concentrated. The residue was purified by column chromatography on silica gel eluted with ethyl acetate-methanol-triethylamine $(100: 5: 2)$, and the desired fractions were concentrated to give $1.12 \mathrm{~g}$ of the free base of $\mathbf{6 c}(79 \%$ yield). With $4 \mathrm{~N}$ hydrogen chloride in ethyl acetate, $\mathbf{6 c}$ was obtained as an amorphous. ${ }^{1} \mathrm{H}-\mathrm{NMR}\left(\mathrm{CDCl}_{3}\right) \delta: 1.32(3 \mathrm{H}, \mathrm{t}$, $J=6.9 \mathrm{~Hz}), 1.85(6 \mathrm{H}, \mathrm{s}), 1.74-2.18(6 \mathrm{H}, \mathrm{m}), 2.34-2.56(2 \mathrm{H}, \mathrm{m}), 2.90-$ $3.10(6 \mathrm{H}, \mathrm{m}), 3.30-3.42(2 \mathrm{H}, \mathrm{m}), 3.82-3.90(1 \mathrm{H}, \mathrm{m}), 4.26(2 \mathrm{H}, \mathrm{q}$, $J=6.9 \mathrm{~Hz}), 5.43(1 \mathrm{H}, \mathrm{s}), 7.19-7.60(12 \mathrm{H}, \mathrm{m}), 8.00(1 \mathrm{H}, \mathrm{s}), 8.74(1 \mathrm{H}, \mathrm{br} \mathrm{s})$, $12.20(1 \mathrm{H}, \mathrm{brs})$. IR $(\mathrm{KBr}) \mathrm{cm}^{-1}: 2940,2650,1730,1490$. Anal. Calcd for $\mathrm{C}_{34} \mathrm{H}_{44} \mathrm{~N}_{4} \mathrm{O}_{3} \mathrm{Cl}_{2} \cdot \mathrm{H}_{2} \mathrm{O}: \mathrm{C}, 63.25 ; \mathrm{H}, 7.18 ; \mathrm{N}, 8.68$. Found: $\mathrm{C}, 63.10 ; \mathrm{H}, 7.43$; $\mathrm{N}, 8.64$.

2-[6-[[3-[4-(Diphenylmethoxy)piperidino]propyl]amino]imidazo[1,2b]pyridazin-2-yl]-2-methylpropionic Acid Dihydrate (6o) To a suspension of $6 \mathbf{a}(31.5 \mathrm{~g}, 40.0 \mathrm{mmol})$ in ethyl acetate $(200 \mathrm{ml})$ and water $(40 \mathrm{ml})$ was added $1 \mathrm{~N}$ aqueous solution of sodium hydroxide $(175 \mathrm{ml}, 175 \mathrm{mmol})$ at $0{ }^{\circ} \mathrm{C}$, and the mixture was stirred vigorously. The aqueous layer was separated and extracted with ethyl acetate. The combined organic layer was washed with water and concentrated. The residue was dissolved in ethanol $(20 \mathrm{ml})$, and addition of $2 \mathrm{~N}$ aqueous solution of sodium hydroxide $(40 \mathrm{ml}$, $80 \mathrm{mmol}$ ) to the solution was followed by stirring at $45^{\circ} \mathrm{C}$ for $6 \mathrm{~h}$. After cooling, $1 \mathrm{~N}$ hydrochloric acid $(80 \mathrm{ml}, 80 \mathrm{mmol})$ was added dropwise to the reaction mixture. The mixture was stirred at $60^{\circ} \mathrm{C}$, and a few seed crystals were added. After $20 \mathrm{~min}$, the mixture was cooled to $0^{\circ} \mathrm{C}$, the crystalline precipitate was collected by filtration and washed with water and diethyl ether to give crude 60 ( $20.5 \mathrm{~g}, 91 \%$ yield). Crude $\mathbf{6 0}(25.6 \mathrm{~g})$ was dissolved in methanol containing small amount of water $(300 \mathrm{ml})$ at $80^{\circ} \mathrm{C}$ and water $(60 \mathrm{ml})$ was added with stirring. After cooling to room temperature, the resulting crystals were collected by filtration, washed with water, and dried to give $23.3 \mathrm{~g}$ of $\mathbf{6 o}, \mathrm{mp} 109-112^{\circ} \mathrm{C}$. ${ }^{1} \mathrm{H}-\mathrm{NMR}$ (DMSO- $\left.d_{6}\right) \delta$ : $1.48(6 \mathrm{H}, \mathrm{s}$ ), $1.45-2.12(8 \mathrm{H}, \mathrm{m}), 2.28-2.40(2 \mathrm{H}, \mathrm{m}), 2.60-2.78(2 \mathrm{H}, \mathrm{m}), 3.12-3.26$ $(3 \mathrm{H}, \mathrm{m}), 5.62(1 \mathrm{H}, \mathrm{s}), 6.58(1 \mathrm{H}, \mathrm{d}, J=9.6 \mathrm{~Hz}), 6.85(1 \mathrm{H}, \mathrm{br} \mathrm{s}), 7.16-7.38$ $(10 \mathrm{H}, \mathrm{m}), 7.56(1 \mathrm{H}, \mathrm{d}, J=9.6 \mathrm{~Hz}), 7.61(1 \mathrm{H}, \mathrm{s}) . \mathrm{IR}(\mathrm{KBr}) \mathrm{cm}^{-1}: 3260,2940$, 1620, 1570, 1490. Anal. Calcd for $\mathrm{C}_{31} \mathrm{H}_{37} \mathrm{~N}_{5} \mathrm{O}_{3} \cdot 2 \mathrm{H}_{2} \mathrm{O}: \mathrm{C}, 66.05 ; \mathrm{H}, 7.33 ; \mathrm{N}$, 12.42. Found: C, 66.14; H, 7.10; N, 12.66 .

Histamine-Induced Contractile Response Using Isolated Tracheal Strips of Guinea Pigs Male std: Hartley guinea pigs weighing 450-800 g were used. The animals were sacrificed by bleeding, and the trachea was isolated. Tracheal strips were prepared according to a minor modification of the method of Takagi et al. ${ }^{24)}$ The preparation was suspended in a $20 \mathrm{ml}$ organ bath containing aerated Tyrode's solution at $37^{\circ} \mathrm{C}$. An initial tension of $1 \mathrm{~g}$ was loaded.

Test compounds at $10^{-5} \mathrm{M}$ were added to the organ bath after the contraction caused by histamine at $10^{-5} \mathrm{M}$ reached a plateau. After $30 \mathrm{~min}$, isoproterenol at $10^{-7} \mathrm{M}$ was added to observe the maximal relaxation level.

The above described isotonic contractile responses were recorded on a polygraph (Saneisokuki Recti-Hori-8K) with an isotonic transducer (MEC ME4021 medical agent IT-10).

Inhibitory activity was calculated using the equation, (histamine-induced contraction inhibition rate $\left(\mathrm{H}_{1}\right.$ in vitro, $\%$ inh. $\left.)\right)=($ relaxation caused by test compounds $(\mathrm{mm})) /($ relaxation caused by isoproterenol $(\mathrm{mm})) \times 100$.

Histamine-Induced Skin Reactions in Guinea Pigs Male std: Hartley guinea pigs were used. Under light ether anesthesia, $0.3 \mu \mathrm{g}$ of histamine was injected intradermally (i.d.) in a volume of $0.1 \mathrm{ml}$ at two points on the shaved back immediately after intravenous injection (i.v.) of $1 \mathrm{ml}$ of $2.5 \%$ Pontamine sky blue. The animals were sacrificed by bleeding $30 \mathrm{~min}$ after the histamine injection and the skin was removed for determination of the area of bluing spots. The area of bluing spots was used as a measure of the increase in microvascular permeability in the skin caused by histamine.

Compounds were suspended in a $5 \%$ gum arabic solution and administered p.o. in a volume of $0.2 \mathrm{ml}$ per $100 \mathrm{~g}$ body weight $1 \mathrm{~h}$ before the histamine injection.

Suppression of Chemotactic Reactions Using Guinea Pig Eosinophils (1) Preparation of Guinea Pig Eosinophils: To male Hartley guinea pigs, $2 \mathrm{ml}$ of equine serum (Bio-Whittaker, Inc.) was intraperitoneally administered once weekly for 8 consecutive weeks. At $48 \mathrm{~h}$ after the final administration, $75 \mathrm{ml}$ of physiological saline was intraperitoneally injected under light ether anesthesia, after which the saline was recovered and centrifuged at $400 \times$ for $5 \mathrm{~min}$. The resulting sediment was suspended in $5 \mathrm{ml}$ of Percoll solution (density $(d)=1.07)$ and layered on top of multiple layers of different densities of Percoll solution (density $(d)=1.112,5 \mathrm{ml} ; d=1.095,10 \mathrm{ml}$; $d=1.090,10 \mathrm{ml} ; d=1.085,5 \mathrm{ml}$ ), before being centrifuged at $1000 \times \boldsymbol{g}$ for 
$25 \mathrm{~min}\left(20^{\circ} \mathrm{C}\right)$. The cell layer that formed at the interface between densities 1.112 and 1.095 was collected. Erythrocytes present in the collected cell sediment were removed by hypotonic treatment (suspended in water for $30 \mathrm{~s})$.

The cell sediment was washed 3 times with Hanks' solution containing $10 \mathrm{~mm}$ Hepes (Dojin Kagaku) (Hanks-Hepes) and suspended in a HanksHepes solution containing 2\% human serum albumin (Wako Pure Chemical Industry or Sigma) (Hanks-Hepes-HSA) to a final concentration of $5.56 \times$ $10^{6}$ cells $/ \mathrm{ml}$. Eosinophil purity was $90 \%$, viability being over $98 \%$.

(2) Evaluation of the Suppression Chemotactic Reactions: To a 24-well petri dish, serving as a lower chamber, $600 \mu$ l of Hanks-Hepes-HSA solution containing $\mathrm{LTB}_{4}$ (final concentration of $10^{-8} \mathrm{M}$, Cascade Biochemical Ltd.) was transferred, and incubation was performed at $37^{\circ} \mathrm{C}$ for $30 \mathrm{~min}$ in a carbon dioxide incubator. Separately, $200 \mu \mathrm{l}$ of eosinophil suspension $\left(5 \times 10^{6}\right.$ cells $/ \mathrm{ml}$ ), previously incubated at $37^{\circ} \mathrm{C}$ for $15 \mathrm{~min}$, was added to Chemotaxicell (polycarbonate membrane pore size $3 \mu \mathrm{m}$, thickness $10 \mu \mathrm{m}$ ), which serves as an upper chamber, after the upper chamber was attached to the 24well petri dish. After $2 \mathrm{~h}$ of reaction in the carbon dioxide incubator, the Chemotaxicell was removed; $60 \mu \mathrm{l}$ of a $2 \%$ (w/v) solution of ethylenediaminetetraacetic acid in physiological saline was added to the liquid in the lower chamber. After the mixture had cooled on ice, the cells migrating into the lower chamber were enumerated using a blood cell counter [Coulter Counter (trade name)]. A test compound, dissolved in $N, N$-dimethylformamide, was added to both the upper and lower chambers to a final concentration of $10^{-5} \mathrm{M}$

Inhibitory activity was calculated using the equation, (chemotactic reaction suppression rate $(\%))=[1$-(number of migrating cells in the presence of compound/number of migrating cells in the absence of compound)] $\times 100$.

Ex Vivo Radioligand Assay in Guinea Pigs Male std: Hartley guinea pigs were used. Compounds were administered orally. One hour later, the animals were sacrificed by decapitation, and their lungs and cerebral cortexes were removed and homogenized. Nuclei and cell debris were spun down at $1000 \times \boldsymbol{g}$ for $10 \mathrm{~min}$ and the crude membrane fraction was obtained at $50000 \times \boldsymbol{g}$ for $10 \mathrm{~min}$. The pellets were resuspended in assay buffer at a protein concentration of $1.0 \mathrm{mg} / \mathrm{ml}$. Then the specific binding of $\left[{ }^{3} \mathrm{H}\right]$ pyrilamine at $2 \mathrm{~nm}$ to the membranes from lung and cerebral cortex was determined. Since the $K_{\mathrm{d}}$ values of $\left[{ }^{3} \mathrm{H}\right]$ pyrilamine for the $\mathrm{H}_{1}$ receptors from lung and cerebral cortex were 0.52 and $0.58 \mathrm{~nm}$, respectively, a decrease in the specific binding of $\left[{ }^{3} \mathrm{H}\right]$ pyrilamine at $2 \mathrm{nM}$ reflects the in vivo occupancy of $\mathrm{H}_{1}$ receptors by test compounds.

OVA-Induced Eosinophil Infiltration in Sensitized Guinea Pigs ${ }^{20)} \quad \mathrm{Fe}-$ male std: Hartley guinea pigs weighing $250-300 \mathrm{~g}$ were anesthetized with an intramuscular injection of a combination of ketamine $(35 \mathrm{mg} / \mathrm{kg})$ and $\mathrm{xy}-$ lazine $(3 \mathrm{mg} / \mathrm{kg}$ ). To sensitized animals, $10 \mu \mathrm{g}$ of OVA mixed with $0.5 \mathrm{mg}$ of $\mathrm{Al}(\mathrm{OH})_{3}$ was injected intradermally at 4 sites on the shaved shoulder. One and three weeks later, the animals were epicutaneously sensitized with $10 \%$ OVA containing 10 and $5 \%$ sodium dodecylsulfate on the shaved back for $48 \mathrm{~h}$, respectively.

One week after the last sensitization, a challenge was carried out by bilateral topical application of $10 \%$ OVA on the shaved flank areas for $24 \mathrm{~h}$ Forty-eight hours after the challenge, the challenged sites were punched out and processed for histological determination. The sections were stained with Luna staining, and then eosinophil infiltration into the dermis was evaluated. Twelve consecutive high power fields $(\times 200)$ on each side were selected for counting eosinophils in the papillary layer of the dermis, and the numbers of eosinophils per $\mathrm{mm}$ were calculated.

Compounds were suspended in a $5 \%$ gum arabic solution and administered p.o. twice daily for $3 \mathrm{~d}$ beginning the day before the OVA challenge.
Dr. Masashi Yamasaki, Ms. Miho Fujisawa, and Mr. Nobuhiro Fujii for providing useful information concerning their synthetic work and the biological evaluation.

\section{References and Notes}

1) Donald Y. M. L., J. Allergy Clin. Immunol., 105, 860-876 (2000).

2) Koro O., Furutani K., Hide M., Yamada S., Tamamoto S., J. Allergy Clin. Immunol., 103, 663-670 (1999).

3) Czech W., Krutmann J., Schöpf E., Kapp A., Br. J. Dermatol., 126, $351-355$ (1992).

4) Leiferman K. M., Ackerman S. J., Sampson H. A., Haugen H. S., Venencie P. Y., Gleich G. J., N. Engl. J. Med., 313, 282-285 (1985).

5) Yanai K., Ryu J. H., Watanabe T., Iwata R., Ido T., Sawai Y., Ito K., Itoh M., Br. J. Pharmacol., 116, 1649-1655 (1995).

6) Kuwahara M., Kawano Y., Kajino M., Ashida Y., Miyake A., Chem. Pharm. Bull., 45, 1447-1457 (1997).

7) Kawano Y., Kuwahara M., Matsumoto T., Ashida Y., Miyake A., 15th Symposium on Medicinal Chemistry, Osaka, Japan, 1994, Abstract of papers, pp. 105-106.

8) Le Goff E., J. Org. Chem., 29, 2048-2050 (1964).

9) Steck E. A., Brundage R. P., Fletcher L. T., J. Am. Chem. Soc., 76, 3225-3226 (1954)

10) Stanovnik B., Stimac A., Tisler M., Vercek B., J. Heterocyclic Chem., 19, 577-583 (1982).

11) Polanc S., Vercek B., Stanovnik B., Tisler M., Tetrahedron Lett., 1973, 1677-1680 (1973).

12) Miyake A., Kawano Y., Ashida Y., Eur. Pat. Appl. EP562439 (1994) [Chem. Abstr., 120, 134502 (1994)].

13) Ochiai M., Morimoto A., Matsushita Y., Kaneko T., Kida M., J. Antibiot., 33, 1005-1013 (1980).

14) Zhang M.-Q., Wada Y., Sato F., Timmerman H., J. Med. Chem., 38, 2472-2477 (1995)

15) Jilek J., Holubek J., Svatek E., Metys J., Frycova H., Pomykacek J., Protiva M., Collect. Czech. Chem. Commun., 53, 870-883 (1988).

16) Walsh D. A., Franzyshen S. K., Yanni J. M., J. Med. Chem., 32, 105118 (1989).

17) Honig P. K., Woosley R. L., Zamani K., Conner D. P., Cantilena L. R., Clin. Pharmacol. Ther, 52, 231-238 (1992).

18) Garteiz D. A., Hook R. H., Walker B. J., Okerholm R. A., Arzneim. Forsch., 32, 1185-1190 (1982).

19) The ester of $6 \mathbf{a}$ was revealed to be hydrolyzed into the carboxylic acid in vivo as shown in the next section. This type of other ester compound is supposed to be the same as $\mathbf{6 a}$. The carboxylic acid derivative 6n showed as potent an antihistaminic effect in vitro and in vivo as the corresponding ester derivative $\mathbf{6 b}$ (data not shown). Therefore, it is possible that $\mathbf{6 n}$ is administered instead of $\mathbf{6} \mathbf{b}$ in comparing BBB permeability between $\mathbf{6 b}$ and the other ester compounds.

20) Fukuda S., Midoro K., Kamei T., Ishisaka Y., Gyoten M., Kawano Y., Ashida Y., Nagaya H., J. Pharmacol. Exp. Ther, 303, 1283-1290 (2002).

21) Nishikawa Y., Shindo T., Ishii K., Nakamura H., Kon T., Uno H., Chem. Pharm. Bull., 37, 100-105 (1989).

22) Nishikawa Y., Shindo T., Ishii K., Nakamura H., Kon T., Uno H., J. Med. Chem., 32, 583-593 (1989).

23) Scheffler G., Engel J., Kutscher B., Sheldrick W. S., Bell P., Arch. Pharm., 321, 205-208 (1988).

24) Takagi K., Takayanagi I., Fujie K., Chem. Pharm. Bull., 6, 716-720 (1958). 